Article

\title{
Ginseng Stem-Leaf Saponins in Combination with Selenium Promote the Immune Response in Neonatal Mice with Maternal Antibody
}

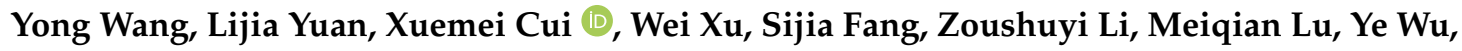 \\ Xiaodan Ma, Xiaoqing Chi and Songhua $\mathrm{Hu}$ *(D) \\ Department of Veterinary Medicine, College of Animal Sciences, Zhejiang University, 866 Yu Hang Tang Rd., \\ Hangzhou 310058, China; wyuan526@zju.edu.cn (Y.W.); 11617034@zju.edu.cn (L.Y.); maycui@zju.edu.cn (X.C.); \\ zhihong0902@zju.edu.cn (W.X.); fangsj@zju.edu.cn (S.F.); 21817088@zju.edu.cn (Z.L.); \\ 21717084@zju.edu.cn (M.L.); 3130100283@zju.edu.cn (Y.W.); maxiaodan@zju.edu.cn (X.M.); \\ tiffany1127@zju.edu.cn (X.C.) \\ * Correspondence: songhua@zju.edu.cn; Tel.: +86-0571-88982852
}

Received: 9 October 2020; Accepted: 10 December 2020; Published: 11 December 2020

check for updates

\begin{abstract}
Neonates acquire from their mothers maternal antibody (MatAb) which results in poor immune response to vaccination. We previously demonstrated that ginseng stem-leaf saponins in combination with selenium (GSe) had adjuvant effect on the immune response to an attenuated pseudorabies virus $(\mathrm{aPrV})$ vaccine. The present study was to evaluate GSe for its effect on the immune response to $\mathrm{aPrV}$ vaccine in neonatal mice with MatAb. Results showed that GSe had adjuvant effect on the immune response to $\mathrm{aPrV}$ vaccine in neonates. When GSe was co-administered with $\mathrm{aPrV}$ vaccine (aP-GSe), specific gB antibody, Th1 cytokines (IL-2, IL-12 and IFN- $\gamma$ ) and Th2 cytokines (IL-4, IL-6 and IL-10) responses were significantly increased in association with enhanced protection of vaccinated neonates against the lethal PrV challenge even though MatAb existed when compared to the neonates immunized with aPrV vaccine alone. GSe-enhanced immune response depended on its use in the primary immunization. The mechanisms underlying the adjuvant effect of GSe may be due to more innate immune related pathways activated by GSe. Transcriptome analysis of splenocytes from neonates immunized with aP-GSe, aPrV or saline solution showed that there were 3976 differentially expressed genes (DEGs) in aP-GSe group while 5959 DEGs in aPrV group when compared to the control. Gene ontology (GO) terms and Kyoto encyclopedia of genes and genomes (KEGG) pathways analysis showed that innate immune responses and cytokine productions related terms or pathways were predominantly enriched in aP-GSe group, such as "NOD-like receptor signaling pathway", "Natural killer cell mediated cytotoxicity", "NF-kB signaling pathway", "cytokine-cytokine receptor interaction", and "Th1 and Th2 cell differentiation". Considering the potent adjuvant effect of GSe on $\mathrm{aPrV}$ vaccine in neonatal mice with MatAb, it deserves further investigation in piglets.
\end{abstract}

Keywords: ginseng stem-leaf saponins; selenium; attenuated pseudorabies virus vaccine; adjuvant; neonatal mice; maternal antibody

\section{Introduction}

Neonates and infants are immunologically naive and more susceptible than adults to infectious diseases [1-3]. Enhancement of the passive transfer of maternal antibodies (MatAb) by immunization of the mother is an important strategy to prevent neonates from infection at the early stage of life [4]. However, MatAb is a double-edged sword in young animals: MatAb provides protection while it also interferes with immune responses to vaccination $[1,5,6]$. 
Pseudorabies ( $\mathrm{Pr}$ ) is an infectious disease caused by porcine herpesvirus-1 (SuHV-1), pseudorabies virus (PrV), or Aujeszky's disease virus. PrV usually causes pigs infected, leading to huge amount of economic losses in the pig industry [7]. The infection of $\operatorname{PrV}$ is fatal in piglets and the mortality approaches $100 \%$. Typical manifestation is paralyzed hind limbs which makes the piglets sit in a "dog-like" position, walk in circles or lay recumbent and paddle. The infected piglets often die from disorder of the central nervous system within 24 to $36 \mathrm{~h} \mathrm{[8,9].} \mathrm{Immunization} \mathrm{of} \mathrm{sows} \mathrm{and} \mathrm{piglets} \mathrm{to}$ protect neonates from infection is a common approach to $\operatorname{PrV}$ control [10,11]. However, due to the immature immune system of neonates and the immune suppressive effect of Mat $\mathrm{Ab}$, immunization of neonates often result in reduced, modified or undetectable immune responses in various mammalian species including pigs [12]. After analysis of 14801 swine serum samples in 14 provinces of China during 2012 to 2013, Zou et al. found that 54.29\% of pig herds (158/291) were infected with $\operatorname{PrV}$ although the animals had received $\operatorname{PrV}$ vaccination [13].

There is a period when neonates are susceptible to infectious diseases after MatAb declines and before vaccine-induced immune response arise [1,14]. Pomorska-Mol et al. observed that serum $\operatorname{PrV}$ specific antibody was below the protection level for about 2 weeks when piglets with MatAb were immunized with $\operatorname{PrV}$ vaccine at 12 weeks old $(n=14)$; however, when piglets with MatAb were inoculated with $\operatorname{PrV}$ vaccine for one immunization ( 8 weeks old; $n=13$ ) or twice immunizations ( 1 and 8 weeks old; $n=13)$, the $\operatorname{PrV}$ specific antibody response was below the protection level with a period of at least 8 weeks $[15,16]$. Therefore, searching for an approach to shorten or close the window of susceptibility is of significance for the control of animal infectious diseases.

We previously demonstrated that ginseng stem-leaf saponins in combination with selenium (GSe) could significantly improve the immune responses against an attenuated $\operatorname{PrV}(\mathrm{aPrV})$ vaccine in a mouse model [17]. In the present study, we evaluated the adjuvant effect of GSe on the immune responses to $\mathrm{aPrV}$ vaccine and searched the possibility for shortening or closing the window of susceptibility to infection diseases using GSe in neonatal mice with MatAb by measuring the antibody response and cytokine production. RNA-seq technology was also used to explore the mechanisms underlying of GSe as an adjuvant.

\section{Materials and Methods}

\subsection{Animals}

Six to eight weeks old female and male ICR mice were purchased from Shanghai Laboratory Animal Center Co., Ltd. (Shanghai, China). Mice were housed in cages in an environment with controlled temperature $\left(24 \pm 1{ }^{\circ} \mathrm{C}\right)$ and humidity $(50 \pm 10 \%)$ and with ad libitum food and water.

\subsection{Ethical Statement}

All the experiments pertaining to animals use and their care strictly followed the Guidelines of Laboratory Animals of Zhejiang University and all the protocols were approved by Zhejiang University Animals Ethics Committee (ZJU20160377).

\subsection{Vaccines and Adjuvant}

Inactivated pseudorabies virus ( $\mathrm{InPrV})$ vaccine were purchased from Wuhan Keqian Biology Co., Ltd. (Wuhan, China). Attenuated pseudorabies (aPrV) vaccine was the product of Boehringer Ingelheim (Vetmedica, Inc., Duluth, GA, USA). Standardized ginseng stem-leaf saponins (GSLS) according to Chinese Veterinary Pharmacopoeia were purchased from Hongjiu Ginseng Industry Co., Ltd. (Jilin, China). According to HPLC analysis, it contained ginsenosides Re (16.36\%), Rd $(9.0 \%)$, $\operatorname{Rg} 1$ (6.0\%), Rb2 (3.8\%), Rc (3.7\%), Rb1 (2.4\%), Rf (0.1\%).

Sodium selenite (medical grade) was purchased from Jinping Chemical Technology Co., Ltd. (Shanghai, China). GSLS $(0.3 \mathrm{mg})$ and Se $(0.1 \mathrm{mg})$ were dissolved in $10 \mathrm{~mL}$ sterile saline solution 
and served as GSe solution. GSe solution was sterilized by passing through a $0.22 \mu \mathrm{m}$ filter and the endotoxin level of solutions was below $0.5 \mathrm{EU} / \mathrm{mL}$.

\subsection{Experimental Design for Transfer of Maternal Antibody from Mother to Neonate}

As shown in Figure 1A, female mice $(n=8)$ were intramuscularly (i.m.) inoculated with $\operatorname{InPrV}$ vaccine twice at 14 days interval. They were mated with male mice at 14 days post the booster vaccination and delivered approximately 21 days later. Female mice $(n=8)$ injected with saline solution served as control (non-immunized). After parturition, half of neonates were nursed by their biological mother and the other half were nursed by non-biological mother [18]. Neonates were weaned on day 21 after birth. Blood samples from mothers and neonates for $\operatorname{PrV} \mathrm{gB}$ specific antibody analysis were collected at 7, 14, 21, 28 days after birth.

2.5. Experimental Design for Effect of GSe on the Immune Responses to aPrV Vaccine in Neonates with MatAb about $50 \%$ of Blocking Rate

As shown in Figure 2a, female mice $(n=10)$ were received $0.1 \mathrm{~mL}$ of $\operatorname{InPrV}$ vaccine (diluted 100 folds) twice at 14 days interval and mated with male mice at 14 days after the booster immunization. A total of 60 neonates (weaned on day 21 after birth) with blocking rate of gB antibody at $45-55 \%$ were used and divided into 3 groups ( $n=20$ /group). Then neonates were i.m. injected with an aPrV vaccine $\left(1000 \mathrm{TCID}_{50}, 50 \mu \mathrm{L}\right)$ diluted in saline solution with GSLS and Se (aP-GSe) or saline solution $(\mathrm{aPrV})$. Neonates received saline solution only served as control group. Blood from mothers and neonates were sampled every two days to analyze gB antibody levels. Then neonates ( $n=10 /$ group) were challenged with intraperitoneal (i.p.) injection of $\operatorname{fPrV}\left(5 \times 10^{5} \mathrm{TCID}_{50}\right)$ on day 28 or 49 .

2.6. Experimental Design for Effect of GSe on the Immune Responses to aPrV Vaccine in Neonates with MatAb about $90 \%$ of Blocking Rate

Female mice $(n=15)$ were injected with $0.1 \mathrm{~mL}$ of $\mathrm{InPrV}$ vaccine twice at 14 days apart before mating with male mice. Ninety-six neonates at weaning with blocking rate of $\mathrm{gB}$ antibody $\geq 85 \%$ were selected and divided into three groups ( $n=32$ /group). (a) One immunization with aP-GSe or aPrV was administered after weaning (day 21). Neonates injected with saline solution served as control. Blood samples were collected every two days from mothers and neonates during day 21 to day 69 for analysis of serum gB antibody. (b) Two immunizations with aP-GSe or aPrV were administered at 3 weeks apart. Neonates injected with saline solution served as control. Blood samples were collected every two days from mothers and neonates during day 21 to day 69 for analysis of serum gB antibody. Neonates at their 44 days old ( $n=10$ /group) and 69 days old ( $n=10$ /group) were challenged with i.p. injection of $\mathrm{fPrV}\left(5 \times 10^{5} \mathrm{TCID}_{50}\right)$.

\subsection{Experimental Design for Effect of GSe on Cytokine Production by Neonatal Splenocytes}

Neonates from immunized mothers were assigned into 3 groups (MatAb+; $n=6 /$ group), and neonates from mothers injected with saline solution served as control groups (MatAb-; 3 groups, $n=6$ /group). Both MatAb+ and MatAb- groups were i.m. with aP-GSe, $\mathrm{aPrV}$, and saline solution on day 21, respectively. At 12 days after the vaccination, neonate splenocytes were collected and re-stimulated by $\operatorname{PrV}$ antigen to detect Th1 and Th2 type cytokine productions.

\subsection{Experimental Design for the Effect of GSe on the Primary and Secondary Immunizations}

Neonates from immunized mothers were divided into five groups ( $n=6 /$ group). Groups 1 to 5 received 1st immunization on day 21 with aP-GSe, aP-GSe, $\mathrm{aPrV}, \mathrm{aPrV}$ and saline solution, respectively, and 2nd immunization on day 42 with aP-GSe, aPrV, aP-GSe, aPrV, and saline solution, respectively (Figure 6A). Blood samples were collected from neonates before the primary immunization as well as $7,14,21$ and 28 days after the booster immunization. 


\subsection{Assay for $\operatorname{PrV} g B$ Specific Antibody}

Serum PrV gB specific antibody was analyzed by a commercial blocking ELSA kit (IDEXX, Inc., Westbrook, ME, USA). Briefly, $100 \mu \mathrm{L} /$ well serum samples (diluted 1/2) were added into the antigen-coated plate. During the incubation, $\operatorname{PrV}$ antibodies present in the sample react with antigen on the plate. Subsequent to a wash step, $100 \mu \mathrm{L}$ anti-PrV gB monoclonal antibody conjugate was added to each microplate well and was allowed to compete for the viral antigen. If no PrV gB antibodies are present in the test sample, the conjugate antibodies are free to react with the antigen. Conversely, if $\operatorname{PrV}$ gB antibodies are present in the test sample, the enzyme-conjugated monoclonal antibodies are blocked from reacting with the antigen. Following this incubation period, the unreacted conjugate was removed by washing, and $100 \mu \mathrm{L} /$ well substrate/chromogen solution was added. Then optical density at $650 \mathrm{~nm}$ (OD 650) was measured using the microplate reader (Thermo Fisher Scientific, Waltham, MA, USA). Results were calculated by dividing the OD 650 of the sample by the mean OD 650 of the negative control, resulting in a sample/negative $(\mathrm{S} / \mathrm{N})$ value. The quantity of antibodies to $\operatorname{PrV}$ is inversely proportional to the OD 650 and thus, to the $\mathrm{S} / \mathrm{N}$ value. Therefore, $\mathrm{gB}$ antibody level can be expressed as the blocking rate by the formula $1-\mathrm{S} / \mathrm{N}$.

\subsection{Experimental Design for Transcriptome Analysis}

Neonates from immunized mothers were classified into 3 groups ( $n=3$ /group), and then received immunization on day 21 with aP-GSe, aPrV and saline solution, respectively. After 12 days, spleen was harvested and splenocytes were isolated for transcriptome analysis by RNA-seq technology.

RNA was extracted from the splenocytes using TRIzol reagent (Thermo Fisher Scientific). RNA samples were quantified and qualified using Nanodrop 2000 Spectrophotometer (IMPLEN, Westlake Village, CA, USA) and Agilent 2100 Bioanalyzer (Agilent, Santa Clara, CA, USA), respectively. Library preparation and sequencing were performed at Novogene (Beijing, China). Illumina sequencing libraries were generated using NEBNext ${ }^{\circledR}$ UltraTM RNA Library Prep Kit (Ipswich, MA, USA) following manufacturer's recommendations [19]. The clustering of index-coded samples was based on a cBot Cluster Generation System using TruSeq PE Cluster Kit v3cBot-HS (Illumina, San Diego, CA, USA). After clustering, the library preparations were sequenced on the Illumina Hiseq platform, and then the paired-end reads with $125 \mathrm{bp} / 150$ base pairs were generated.

Index of the reference genome was built using Hisat2 (v2.0.5) and paired-end clean reads were aligned to the reference genome using Hisat2 (v2.0.5). The reference genome of the program is mus musculus grcm38.p6 in the ensembl database (ftp://ftp.ensembl.org/pub/release-92/fasta/mus_ musculus/). The mapped reads of each sample were assembled by StringTie (v1.3.3b) in a reference-based approach. Feature Counts (v1.5.0-p3) was used to count the reads numbers mapped to each gene. And then FPKM of each gene was calculated based on the length of the gene and reads count mapped to this gene. DESeq2 R package (1.16.1) was employed to analyze the differentially expression genes (DEGs), the resulting $\mathrm{P}$ values were adjusted using the Benjamini and Hochberg's. Genes with $p<0.05$ and fold changes above 2 were defined as DEGs [19]. Additionally, Gene Ontology (GO; http://geneontology.org) and Kyoto Encyclopedia of Genes and Genomes (KEGG; http://www.genome. $\mathrm{jp} / \mathrm{kegg} /$ ) database were used to analyze GO and KEGG pathways of the DEGs $[20,21]$.

\subsection{Validation of Gene Expression by RT-qPCR}

Twelve DEGs (relative fold changes were above $4 \log _{2}$ ) were chosen randomly to verify the data of RNA-seq by RT-qPCR. Primers sequences used for RT-qPCR (http://www.ncbi.nlm.nih.gov/) were synthesized by Sangon Biotech (seen in Table 1). Quantitative PCR was performed using SYBR ${ }^{\circledR}$ Premix Ex TaqTM II (Tli RNaseH Plus) on ABI7300 (PE Applied Biosystems, Waltham, MA, USA) and determined by the $2^{-\Delta \Delta C}$ method [22]. 
Table 1. Sequences of primers for quantitative RT-PCR.

\begin{tabular}{|c|c|}
\hline Gene & Primer Sequence \\
\hline Zfp979 (ENSMUSG00000066000) & $\begin{array}{c}\text { Forward: 5-GCTGGCCTCCTAGGACATTC-3 } \\
\text { Reverse: 5-GGAGCAAACATTCAAGTTCTGGAT-3 }\end{array}$ \\
\hline C2cd4a (ENSMUSG00000047990) & $\begin{array}{l}\text { Forward: 5-TCTGACTCTGAATACCAGGCAGC-3 } \\
\text { Reverse: 5-GGTCTGGAGTGAGCACGTTT-3 }\end{array}$ \\
\hline Ces1f (ENSMUSG00000031725) & $\begin{array}{l}\text { Forward: 5-TGTAAGACCACCACGTCTGC-3 } \\
\text { Reverse: 5-TGGTCGCTATTTTTGGTATCTCCT-3 }\end{array}$ \\
\hline $\begin{array}{c}\text { Inmt } \\
\text { (ENSMUSG00000003477) }\end{array}$ & $\begin{array}{l}\text { Forward: 5-CCTTTCTGGCCATGGAGTGT-3 } \\
\text { Reverse: 5-TGGAAGCGCAGAGTAACCAG-3 }\end{array}$ \\
\hline $\begin{array}{c}\text { Lilrb4 } \\
\text { (ENSMUSG00000112148) }\end{array}$ & $\begin{array}{l}\text { Forward: 5-GGACCTGCCCTCAAGATGAC-3 } \\
\text { Reverse: 5-GGTTCCAGAATAAGACCTCACCA-3 }\end{array}$ \\
\hline $\begin{array}{c}\text { Gm5771 } \\
\text { (ENSMUSG00000058119) }\end{array}$ & $\begin{array}{l}\text { Forward: 5-TCCCTGTGGATGATGATAAGATCG-3 } \\
\text { Reverse: 5-CACTTGGATGCGGGTTTTGT-3 }\end{array}$ \\
\hline $\begin{array}{c}\text { Gys2 } \\
\text { (ENSMUSG00000030244) }\end{array}$ & $\begin{array}{l}\text { Forward: 5-ATCACCACCAACGACGGA-3 } \\
\text { Reverse: 5-GCСТCСТCTTCСТCATCATACC-3 }\end{array}$ \\
\hline $\begin{array}{c}\text { Tmprss13 } \\
\text { (ENSMUSG00000037129) }\end{array}$ & $\begin{array}{c}\text { Forward: 5-CCAGGTCTCAGTTTCCCCAA-3 } \\
\text { Reverse: 5-CTCTCCAGAAGTAGAAGAGAAGG-3 }\end{array}$ \\
\hline $\begin{array}{c}\text { Ighv5-9-1 } \\
\text { (ENSMUSG00000095210) }\end{array}$ & $\begin{array}{l}\text { Forward: 5-GAGATGGTGAATCGGCCCTT-3 } \\
\text { Reverse: 5-GTGCAGCCTCTGGATTCACT-3 }\end{array}$ \\
\hline $\begin{array}{c}\text { Olfr56 } \\
\text { (ENSMUSG00000040328) }\end{array}$ & $\begin{array}{l}\text { Forward: 5-TCCTATGCTCAACCCCCTCA-3 } \\
\text { Reverse: 5-GGCAAACATCAGGCAACACA-3 }\end{array}$ \\
\hline $\begin{array}{c}\text { Ctrl } \\
\text { (ENSMUSG00000031896) }\end{array}$ & $\begin{array}{l}\text { Forward: 5-ATCAGTGGTGTGGGCAATGT-3 } \\
\text { Reverse: 5-CATGGCATCGGTAATGCGTG-3 }\end{array}$ \\
\hline $\begin{array}{c}\text { Tmed11 } \\
\text { (ENSMUSG00000004821) }\end{array}$ & $\begin{array}{l}\text { Forward: 5-ATCTGCTCCTGGCTTAGGAATG-3 } \\
\text { Reverse: 5-ATATCTAAGTGGATGCGCAGCTT-3 }\end{array}$ \\
\hline $\begin{array}{c}\text { GAPDH } \\
\text { (ENSMUSG00000057666) }\end{array}$ & $\begin{array}{l}\text { Forward: 5-TCG TCC GGT AGA CAA AAT GG-3 } \\
\text { Reverse: 5-GAG GTC AAT GAA GGG GTC GT-3 }\end{array}$ \\
\hline
\end{tabular}

\subsection{Cytokine Assay}

The assay was performed as previously described [17,23]. In brief, splenocytes were isolated from neonates under aseptic conditions and obtained in RPMI 1640 medium (Hyclone, Logan, UT, USA) supplemented with streptomycin $(100 \mu \mathrm{g} / \mathrm{mL})$, penicillin $(100 \mathrm{IU} / \mathrm{mL})$, and $10 \%$ fetal bovine serum (FBS; Hyclone). At a concentration of $5 \times 10^{6}$ cells $/ \mathrm{mL}, 100 \mu \mathrm{L}$ of cells were seeded into 96-well plates and re-stimulated with inactivated $\operatorname{PrV}\left(5 \times 10^{5} \mathrm{TCID}_{50}\right)$ antigen at $37{ }^{\circ} \mathrm{C}$ for $48 \mathrm{~h}$ in $5 \%$ $\mathrm{CO}_{2}$ atmosphere. Afterwards, the supernatants were collected and cytokines IFN- $\gamma$, IL-2, IL-4, IL-6, IL-10 and IL-12 were analyzed by ELISA kits (MultiSciences Biotech, Hangzhou, China) in accordance with the manufacturer's instructions.

\subsection{Statistical Analysis}

GraphPad Prism 7.0 software (GraphPad Software, San Diego, CA, USA) was used to perform the data analysis. Multiple comparisons were conducted by two-way ANOVA with Tukey's multiple comparisons test and Sidak's multiple comparisons test or one-way ANOVA with the LSD test. Statistical differences were considered significant when the $p$ value was $<0.05$.

\section{Results}

\subsection{Transfer of Maternal Antibody from Mother to Neonate}

To evaluate the effect of maternal vaccination on the antibody in neonates, female mice were injected with InPrV vaccine or saline solution and mated with male mice 14 days later. After birth, 
half of the neonates were nursed by their biological mother and the other half were nursed by non-biological mother. Figure 1B shows that serum antibody response was remarkably higher in immunized mothers than non-immunized mothers. Figure $1 \mathrm{C}$ shows that the amount of maternal antibody transferred from mothers to neonates mainly depended on breastfeeding. MatAb in neonates nursed by immunized mothers $(\mathrm{P}+\mathrm{M}+; \mathrm{P}-\mathrm{M}+)$ was remarkably higher than that in neonates nursed by non-immunized mothers although their biological mother might be immunized $(\mathrm{P}+\mathrm{M}-)$.
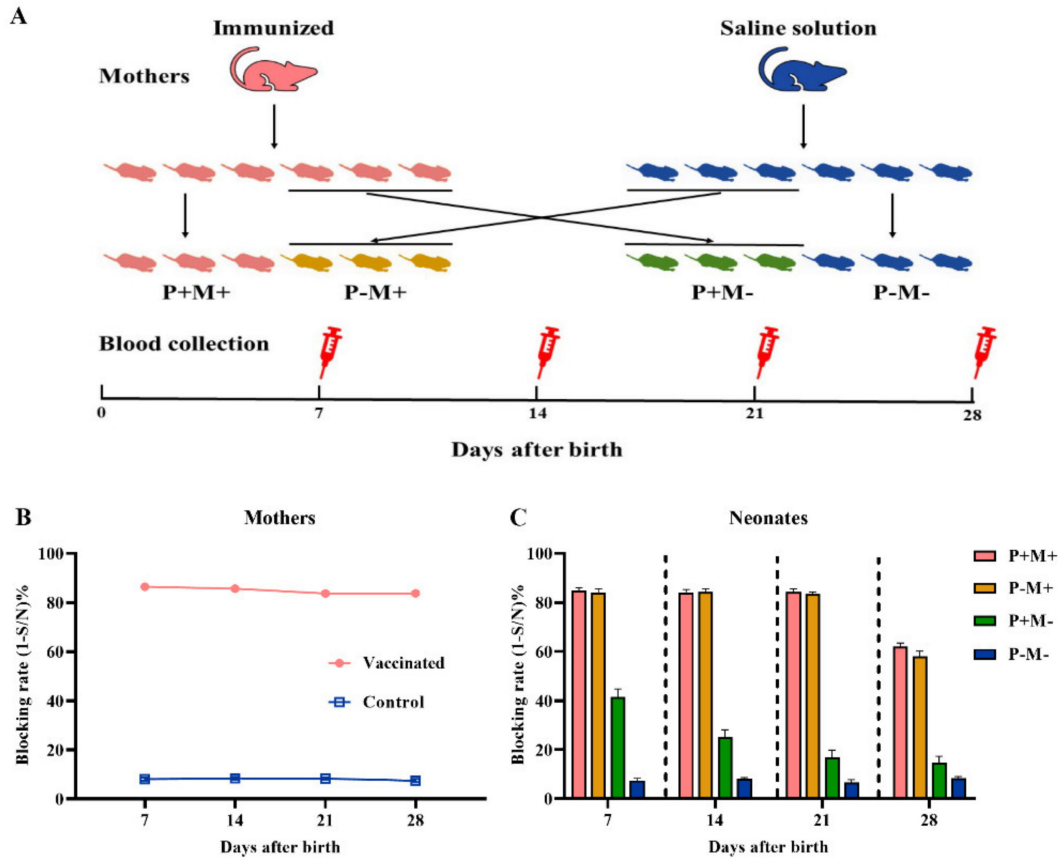

Figure 1. Transfer of maternal antibody from mother to neonate. (A) Schematic diagram for the experiment, female mice $(n=8)$ were intramuscularly (i.m.) injected with $\operatorname{InPrV}$ vaccine and mated with male mice $(n=4) 14$ days later. Dams $(n=8)$ injected with saline solution in the same way served as control (non-immunized). After birth, the neonates in the same litter were divided into two groups. One group was nursed by their biological mother and the other group was nursed by non-biological mother; (B) Serum gB antibody responses of mothers immunized with InPrV vaccine or saline solution; (C) Serum gB antibody responses of neonatal mice. $\mathrm{P}+\mathrm{M}+$, nursed by their own and immunized mother; $\mathrm{P}-\mathrm{M}+$, nursed by immunized mother but their biological mother was not immunized; $\mathrm{P}+\mathrm{M}-$, nursed by non-immunized mother but their biological mother was immunized; $\mathrm{P}-\mathrm{M}-$, nursed by their own and non-immunized mother.

\subsection{Effect of GSe on the Immune Responses to aPrV Vaccine in Neonates with MatAb about 50\% of Blocking Rate}

According to the instruction of test kit, animals with blocking rate of $\mathrm{gB}$ antibody $\geq 30 \%$ are believed positive against PrV infection. Figure $2 b$ shows that all neonates from the day 21 to day 27 post birthday had MatAb above the protective level; MatAb declined less than the protection post day 27 in non-immunized babies; antibody level in neonates immunized with aPrV was below the protection from day 27 to day 40 (13 days); while antibody level in neonates immunized with aP-GSe was below the protection from day 27 to day 36 (9 days).

To evaluate $\mathrm{gB}$ antibody in protection of animals from fPrV challenge, i.p. injection with fPrV was carried out on day 28 and day 49, respectively. Figure 2c shows that all animals challenged on day 28 died within $96 \mathrm{~h}$; the neonates immunized with aPrV had survival rate of $30 \%$ and those immunized with aP-GSe had survival rate of $50 \%$ after challenged on day 49 . 
a
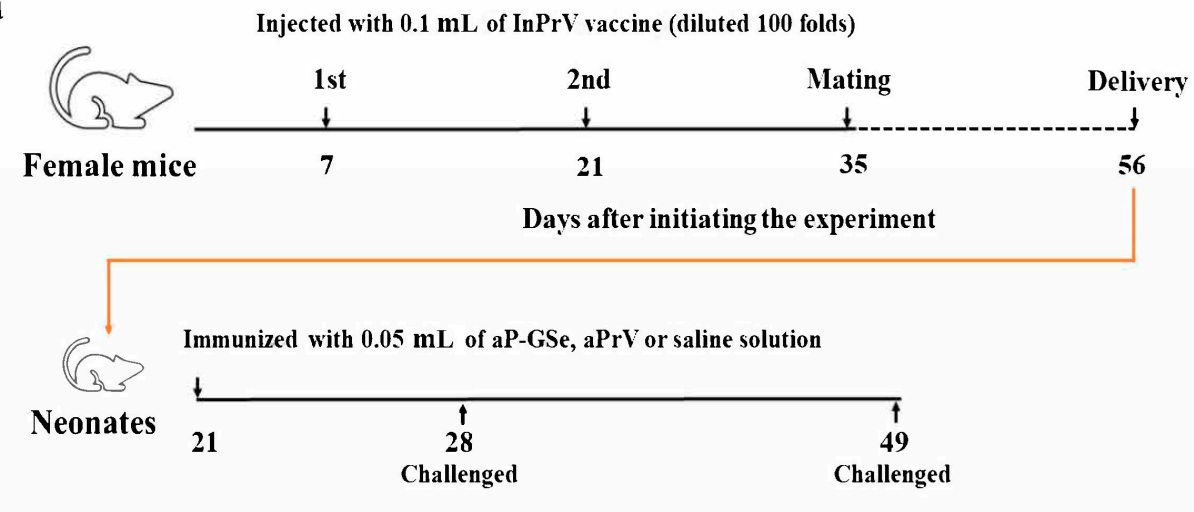

Days post birth

b

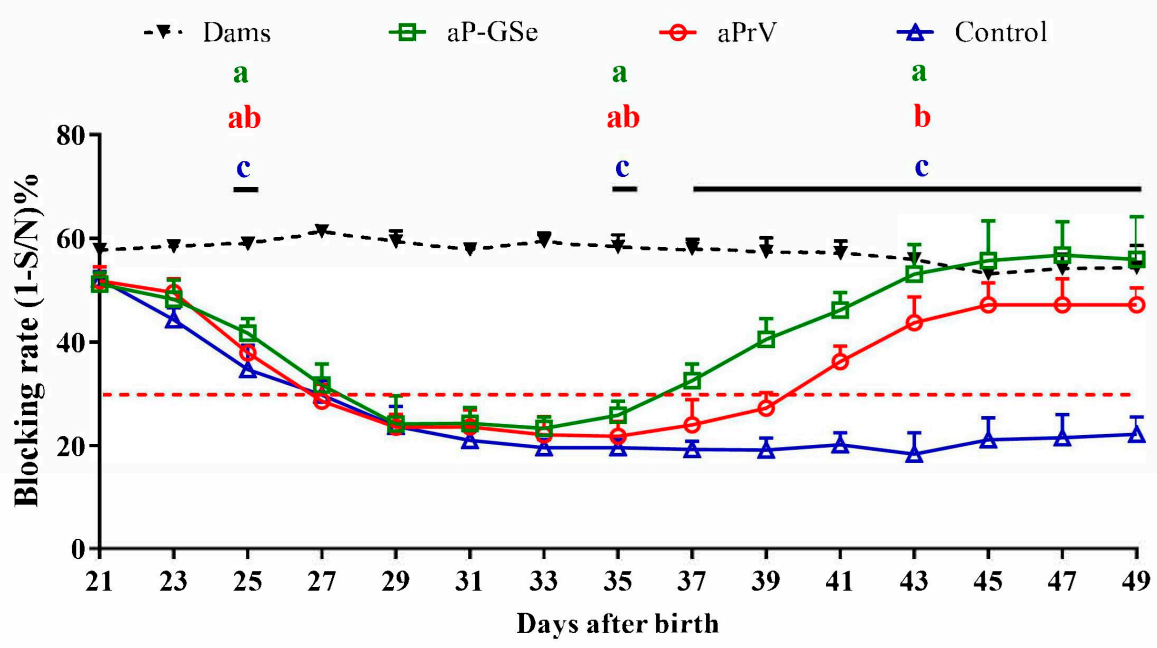

c
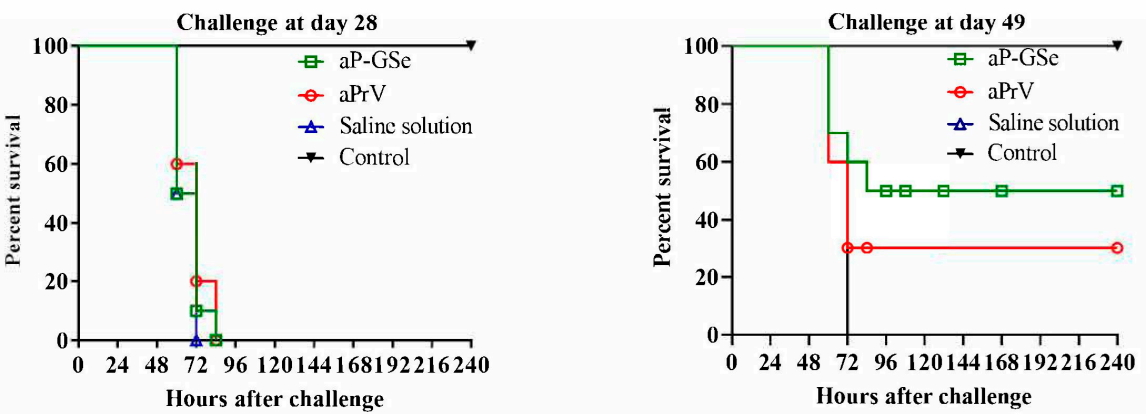

Figure 2. Effect of GSe on the immune responses to $\mathrm{aPrV}$ vaccine in neonates with MatAb about $50 \%$ of blocking rate. (a) Schematic diagram for the experiment; (b) Serum samples were collected from neonates after immunization every two days during the period of day 21 (the day of weaning) to day 49 post birth for analysis of $\mathrm{gB}$ antibody response by a blocking ELISA. Sample with blocking rate of gB antibody $\geq 30 \%$ is considered positive (red dotted line) according to the instruction of kit's manufacturer. Data are expressed as mean \pm SEM. Data with different letters in the same time point were significantly different; (c) The neonates ( $n=10$ /group) were challenged with intraperitoneal (i.p.) injection of $\operatorname{PrV}\left(5 \times 10^{5} \mathrm{TCID}_{50}\right)$ on day 28 or 49 post birth. The animals were monitored for $240 \mathrm{~h}$ and data are presented as percent survival.

3.3. Effect of GSe on the Immune Responses to aPrV Vaccine in Neonates with MatAb about $90 \%$ of Blocking Rate

The immune responses induced by one injection of $\mathrm{aPrV}$ vaccine are shown in Figure $3 \mathrm{~b}$. Neonates non-immunized or receiving immunization of $\mathrm{aPrV}$ had progressively declined Mat $\mathrm{Ab}$ and the Mat $\mathrm{Ab}$ 
quickly dropped below the protection on days 38 and 43, respectively; neonates immunized with aP-GSe always had serum $\mathrm{gB}$ antibody levels above the protection throughout the experiment.

a
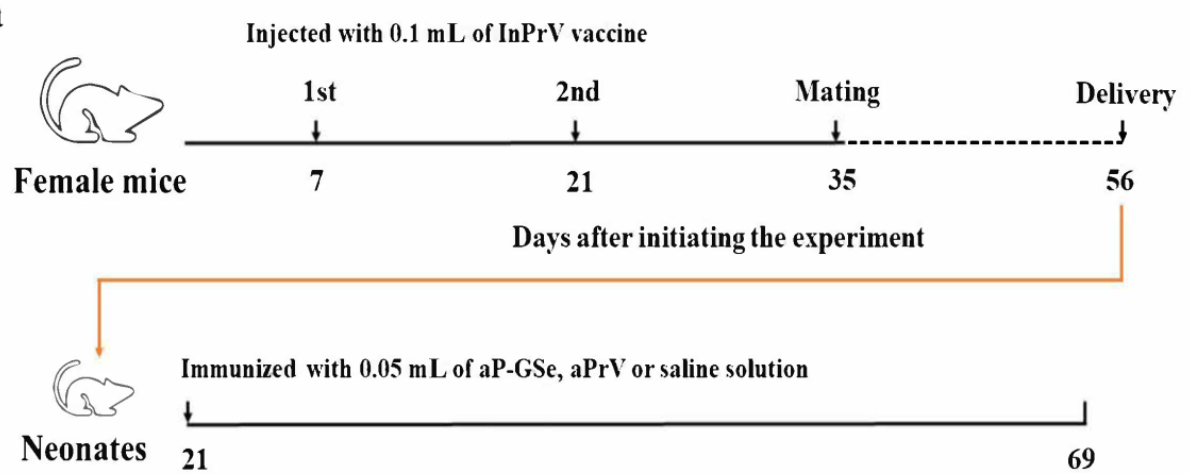

Days post birth

b

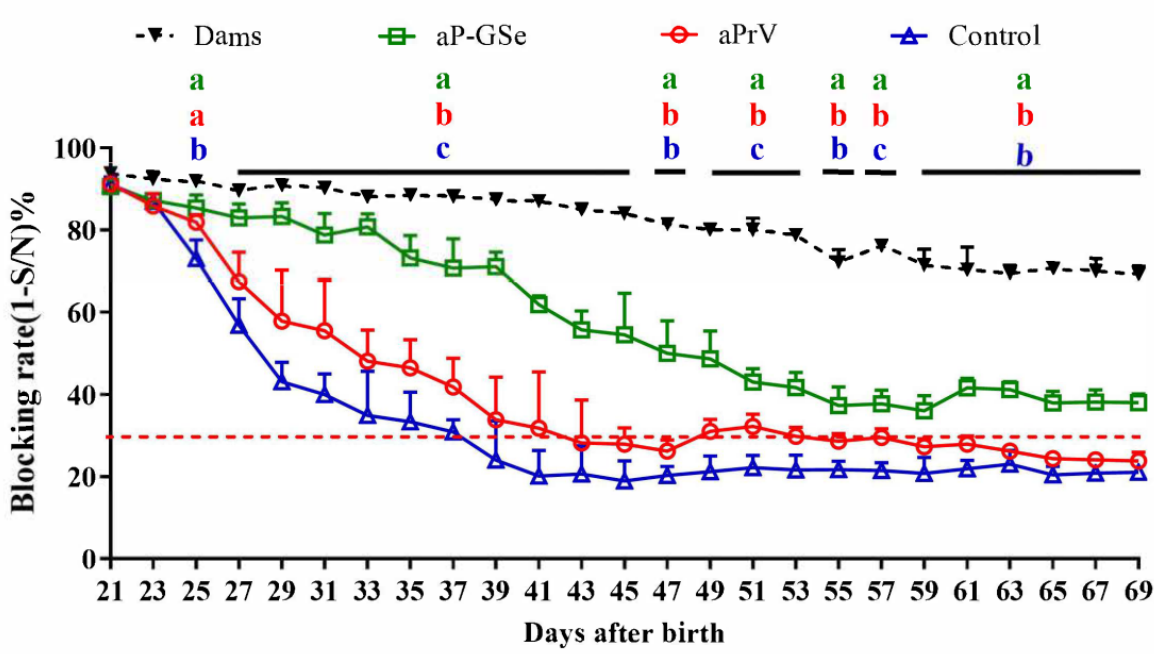

Figure 3. Effect of GSe on the immune response to one immunization of $a \operatorname{PrV}$ vaccine in neonates with about $90 \%$ of MatAb. (a) Schematic diagram for the experiment; (b) Serum samples were collected from neonates every two days during the period of day 21 (the day of weaning) to day 69 post birth for analysis of $\mathrm{gB}$ antibody response by a blocking ELISA. Sample with blocking rate of $\mathrm{gB}$ antibody $\geq 30 \%$ is considered positive (red dotted line) according to the instruction of kit's manufacturer. Data are expressed as mean \pm SEM. Data with different letters in the same time point were significantly different, and the colors of letters were in line with indicated group curves (so as below).

Two injections of aPrV vaccine induced significantly different antibody responses from those induced by just one injection. Figure $4 \mathrm{~b}$ shows that neonates non-immunized or receiving immunization of $\mathrm{aPrV}$ had progressively declined MatAb and the MatAb quickly dropped below the protection on days 38 and 43, respectively; the antibody level rose above the protection after day 56 because of the booster immunization of $\mathrm{aPrV}$ with 14 days of low antibody level. However, neonates immunized with aP-GSe always had serum $\mathrm{gB}$ antibody levels above $30 \%$ of protection throughout the experiment.

Figure 4c shows that no animals survived in the non-immunized and $\mathrm{aPrV}$ groups and $30 \%$ animals survived in aP-GSe group after challenge with $\mathrm{fPrV}$ on day 44; no animals survived in the non-immunized groups but 30 and $60 \%$ of animals survived in neonates immunized with aPrV and aP-GSe, respectively, after challenge on day 69 . 
a
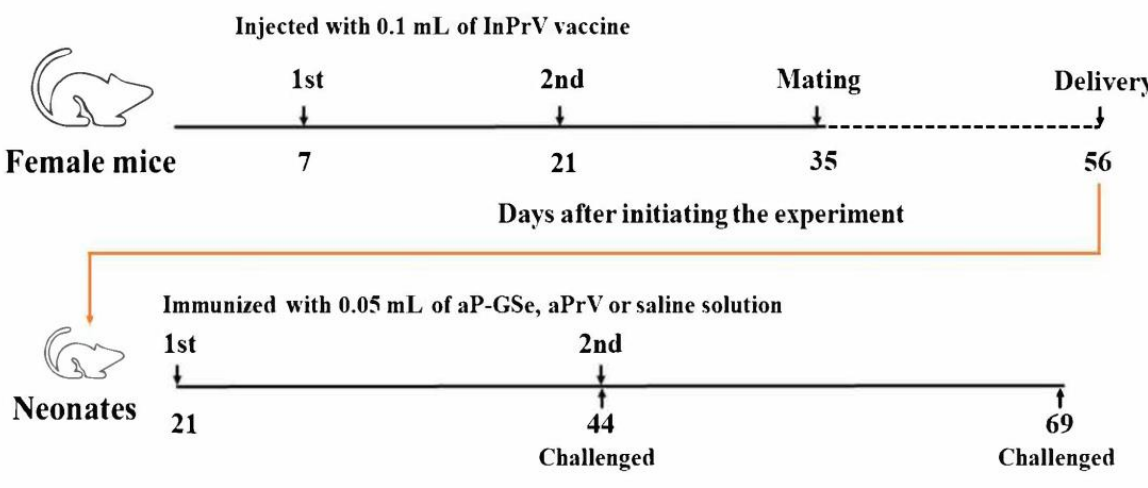

Days post birth

b

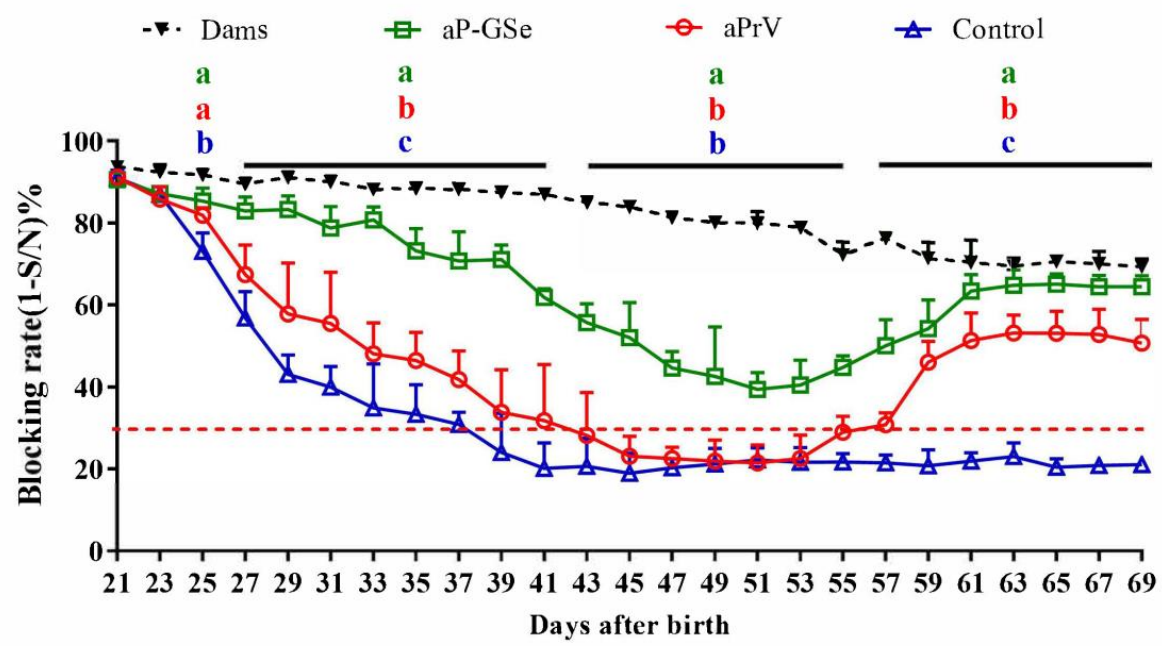

C
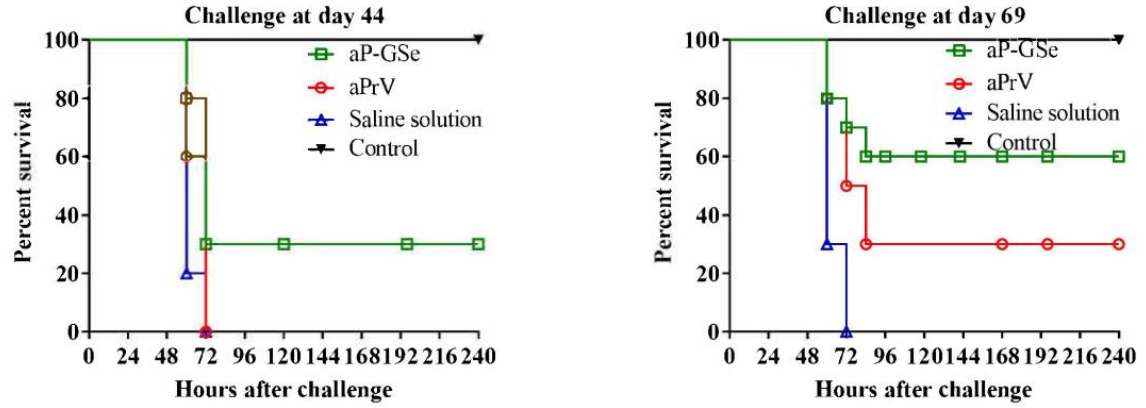

Figure 4. Effect of GSe on the immune response to twice immunizations of aPrV vaccine with three weeks apart in neonates with MatAb about $90 \%$ of blocking rate. (a) Schematic diagram for the experiment; (b) Serum samples were collected from neonates every two days during the period of day 21 (the day of weaning) to day 69 post birth for analysis of $\mathrm{gB}$ antibody response by a blocking ELISA. Sample with blocking rate of $\mathrm{gB}$ antibody $\geq 30 \%$ is considered positive (red dotted line) according to the instruction of kit's manufacturer. Data are expressed as mean \pm SEM. Data with different letters in the same time point were significantly different; (c) The neonates ( $n=10 /$ group) were challenged with intraperitoneal (i.p.) injection of $\operatorname{PrV}\left(5 \times 10^{5} \mathrm{TCID} 50\right)$ on day 44 or 69 post birthday. The animals were monitored for $240 \mathrm{~h}$ and data are presented as percent survival.

\subsection{Effect of GSe on Cytokine Production in Neonates with MatAb}

Generally, cytokine production in MatAb+ groups was less than in MatAb-groups. Figure 5B shows that Th1 cytokines (IL-2, IL-12 and IFN- $\gamma$ ) were significantly less in MatAb+ group than in $\mathrm{Mat} \mathrm{Ab}$ - group when neonates were immunized with $\mathrm{aPrV}$. In addition, although Th2 cytokines (IL-4, 
IL_6 and IL-10) were numerically less in MatAb+ than in MatAb-groups, there was no statistical difference between two groups when aPrV was inoculated (Figure 5C). However, both Th1 and Th2 cytokine productions in MatAb+ and MatAb- groups were significantly higher in animals immunized with aP-GSe than in those immunized with aPrV. The difference for Th1 cytokine production between MatAb+ and MatAb- groups was less in aP-GSe-inoculated neonates than in aPrV-inoculated neonates.

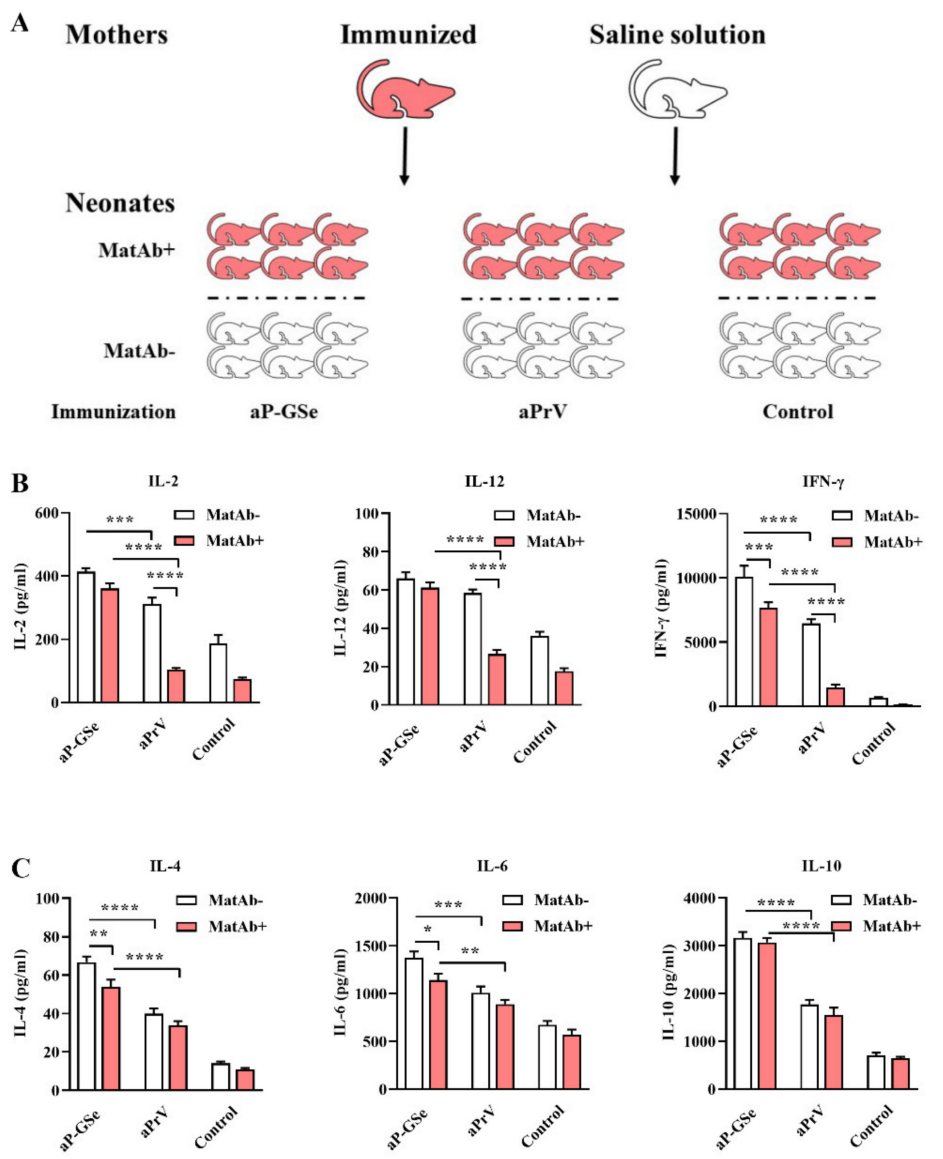

Figure 5. Effect of GSe on cytokine production by lymphocytes of neonates. (A) Schematic diagram for the experiment, neonates with MatAb (+) were from immunized female mice with InPrV vaccine and neonates without MatAb (-) were from mice injected with saline solution. Both MatAb+ and MatAbneonates were injected with aP-GSe, aPrV or salinne solution ( $n=6 /$ group). The spleen was collected 12 days after immunization for isolation of splenocytes, and the cells were cultured with inactivated PrV antigen to detect (B) Th1 cytokines (IL-2, IL-12 and IFN- $\gamma$ ) and (C) Th2 cytokines (IL-4, IL-6 and IL-10). Data are presented as mean \pm SEM. ${ }^{*} p<0.05,{ }^{* *} p<0.01,{ }^{* * *} p<0.001,{ }^{* * * *} p<0.0001$.

\subsection{Effect of GSe on the Primary and Secondary Immunizations in Neonates}

To investigate the effect of GSe on the primary and secondary immunizations, neonates were vaccinated with different combinations of aP-GSe and $\mathrm{aPrV}$ as shown in Figure 6A. Figure 6B shows that aP-GSe + aP-GSe and aP-GSe + aPrV groups had significantly higher antibody response than aPrV $+\mathrm{aPrV}$ and $\mathrm{aPrV}+\mathrm{aP}-\mathrm{GSe}$ groups after the booster immunization. Although GSe was used in the secondary immunization, it did not promote the antibody response if the primary immunization did not include GSe (aPrV + aP-GSe group). 


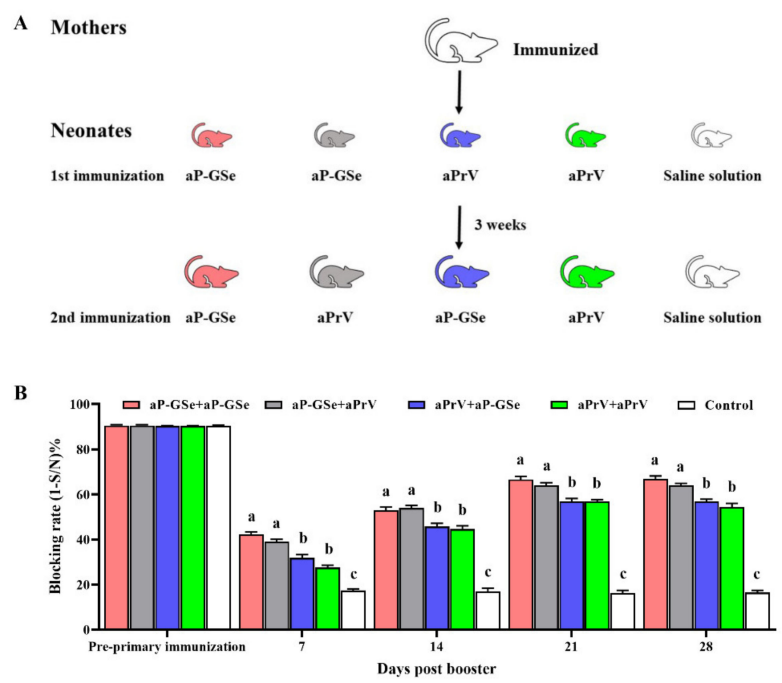

Figure 6. Effect of GSe on the primary and secondary immunizations in neonates. (A) Schematic diagram for the experiment; (B) Neonates with 21 days old were randomly divided into 5 groups and twice immunized at 3 weeks apart with the following vaccine combinations: groups 1, aP-GSe + aP-GSe; group 2, aP-GSe + aPrV; group 3, aPrV + aP-GSe; group 4, $\mathrm{aPrV}+\mathrm{aPrV}$; group 5, saline + saline. Blood samples were collected before the primary and after days 7, 14, 21 and 28 post the booster immunization. Data are presented as mean \pm SEM. Data with significant differences among groups are shown with different letters.

\subsection{DEGs between Neonates Immunized with aP-GSe and aPrV}

Figure 7 shows that there were 3976 DGEs (2357 up- and 1619 down-regulated) in aP-GSe vs. control, 5959 DGEs (2996 up- and 2963 down-regulated) in aPrV vs. control and 125 DGEs (50 up- and 75 down-regulated) in aP-GSe vs. aPrV.
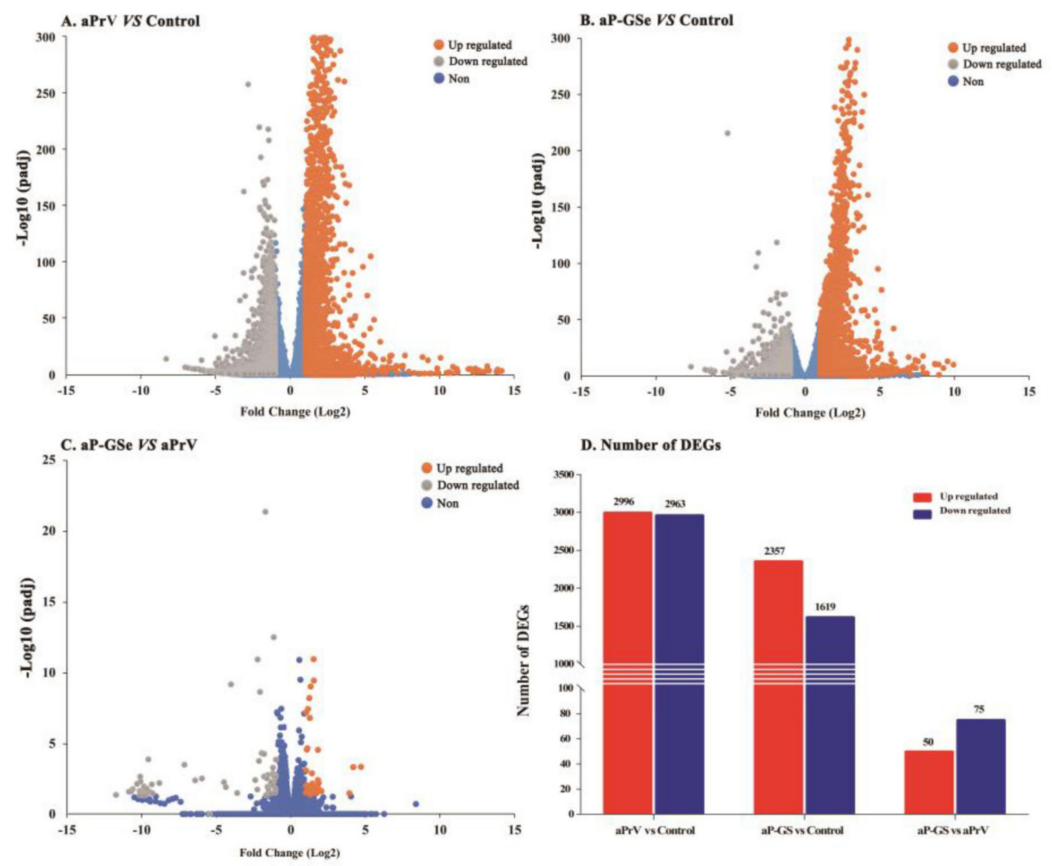

Figure 7. DEGs of three pairs of groups. Neonates ( $n=3$ /group) at 21 days old were i.m. injected with aP-GSe, aPrV or saline solution (control). The spleen was harvested 12 days after the vaccination and splenocytes were isolated for transcriptome sequencing. Volcano plots indicate up-and down-regulated DEGs in (A) aP-GSe vs. control, (B) aPrV vs. control, and (C) aP-GSe vs. aPrV, (D) Number of DEGs. 


\subsection{GO Enrichment Analysis of DEGs}

Analysis of GO enrichment based on DEGs is an important approach to reveal the biological process of mRNAs from three categories including the Biological Process (BP), Molecular Function (MF), and Cellular Component (CC). In the pair of aPrV vs. control (Figure 8A), terms related with immune in the catalog of BP, "antigen receptor-mediated signaling pathway", "regulation of B cell activation", and "regulation of leukocyte cell-cell adhesion". For the CC, "spindle", "condensed chromosome" and "immunoglobulin complex" were the dominant terms, and in the part of the MF section, "antigen binding" and "immunoglobulin receptor binding" were the most represented terms. As shown in Figure 8B, in aP-GSe vs. control, "activation of immune response", "adaptive immune response", "immune response-activating signal", "B cell mediated immunity", "immunoglobulin mediated immune response", "lymphocyte mediated immunity" and "positive regulation of leukocyte activation" were the predominant terms in BP as well as "antigen binding" and "immunoglobulin receptor binding". Furthermore, as compared to $\mathrm{aPrV}$, aP-GSe could modulate the gene enrichment in immune-related terms "MHC protein complex", "antigen binding", "T cell receptor binding", "calcium channel activity", "antioxidant activity", "antimicrobial humoral response", "cellular lipid catabolic process", and "antigen processing and presentation of immune cells" (Figure 8C) which indicated that GSe could modulate more immune related signaling pathways.
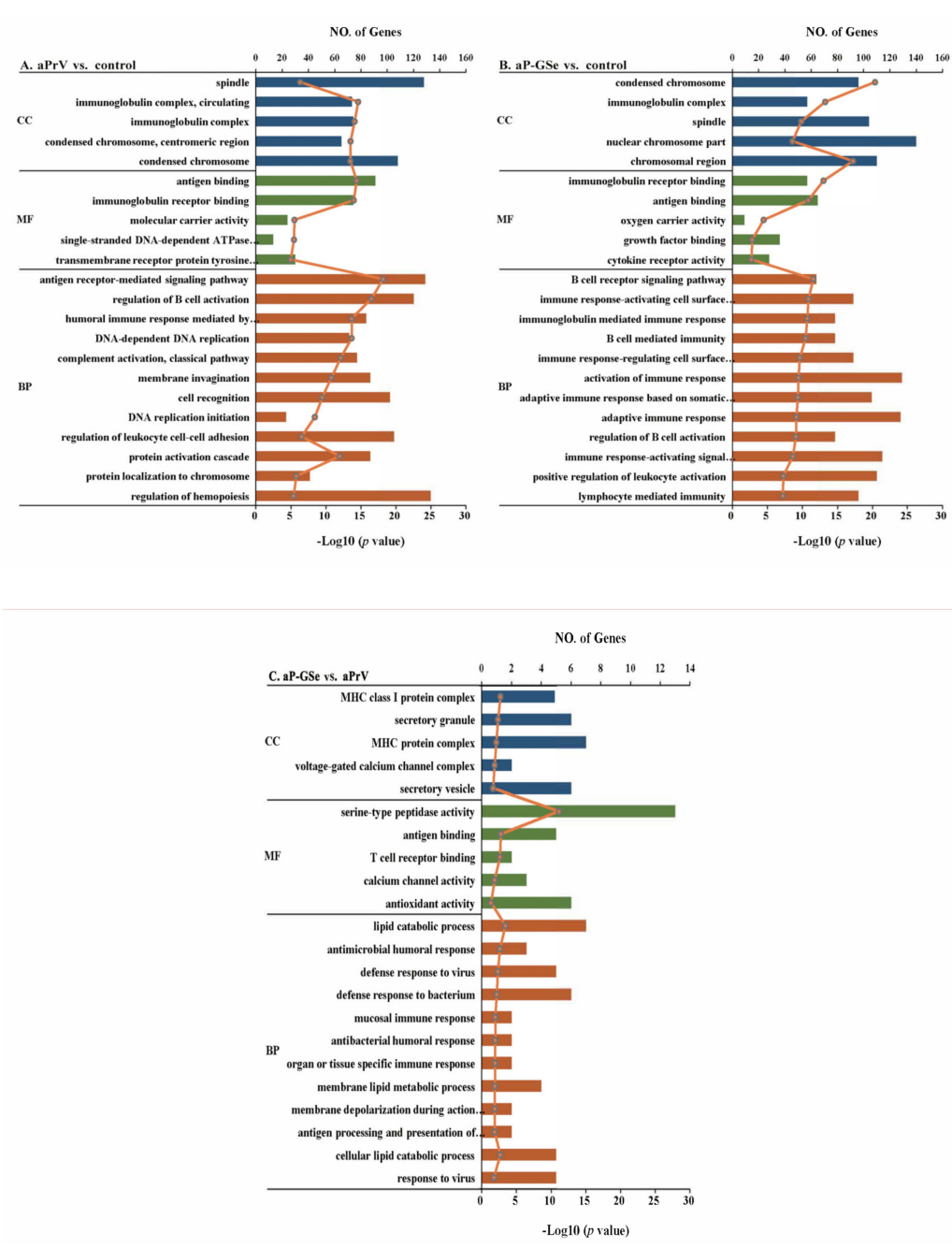

Figure 8. GO functional enrichment analysis. The GO terms were classified based on Gene Ontology. DEGs of (A) aP-GSe vs. control, (B) aPrV vs. control, and (C) aP-GSe vs. aPrV were used for GO functional enrichment analysis. GO terms with corrected $p$ value less than 0.05 were considered significantly enriched by DEGs. 


\subsection{KEGG Pathway Enrichment Analysis of DEGs}

The KEGG database contains the pathway maps representing the knowledge of molecular interaction and reaction networks. Compared with the control group, aPrV modulated immune related pathways including "cytokine-cytokine receptor interaction", "T cell receptor signaling pathway", "Th2 cell differentiation", "C-type lectin receptor signaling pathway", "Toll-like receptor signaling pathway", "TNF signaling pathway", et al. (Figure 9A). For aP-GSe vs. control, aP-GSe group could modulate more immune related pathways such as "NOD-like receptor signaling pathway", "NF-kB signaling pathway", "Natural killer cell mediated cytotoxicity", "Antigen processing and presentation", "T cell receptor signaling pathway", "cytokine-cytokine receptor interaction", "TGF-beta signaling pathway", "Th1 and Th2 cell differentiation", "p53 signaling pathway" and so on (Figure 9B).
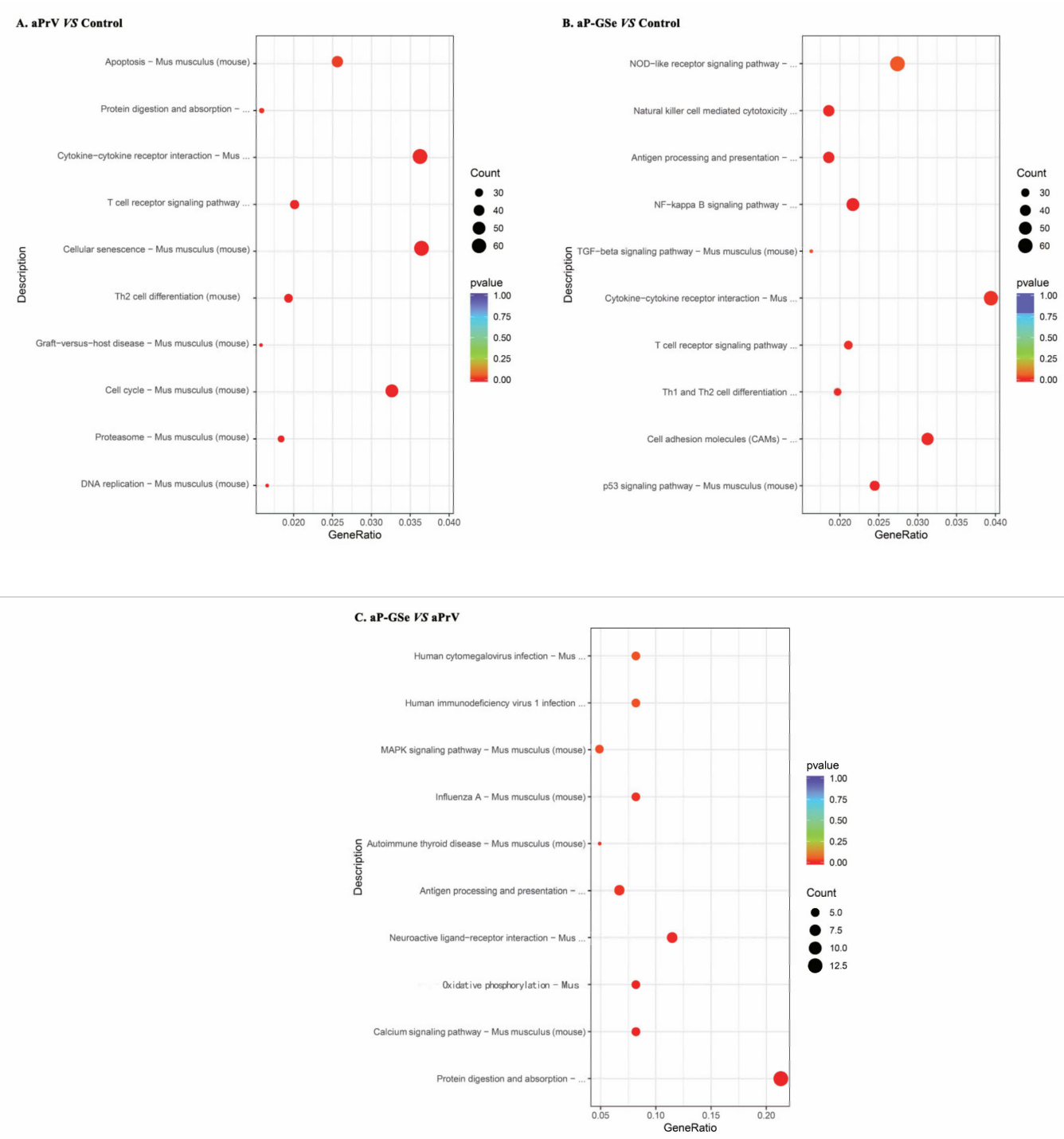

Figure 9. Enrichment of KEGG pathways analysis. DEGs of (A) aP-GSe vs. control, (B) aPrV vs. control, and $(\mathbf{C})$ aP-GSe vs. aPrV were used for KEGG pathways analysis.

There was different pathways enrichment in aP-GSe vs. aPrV group, such as "MAPK signaling pathway", "Antigen processing and presentation", "Calcium signaling pathway", "Protein digestion and absorption" (Figure 9C), and the data of related gene was provided in Supplementary Table S1. These data indicate that GSe enhances immune responses to $\mathrm{aPrV}$ of neonates via involving more immune related pathways 


\subsection{Validation of DEGs by RT-qPCR}

To validate the results of RNA-seq assay, a total of 12 DEGs including up-regulated or down-regulated genes were selected and measured by RT-PCR. Results from Figure 10 suggest the reliability of the RNA-seq test.

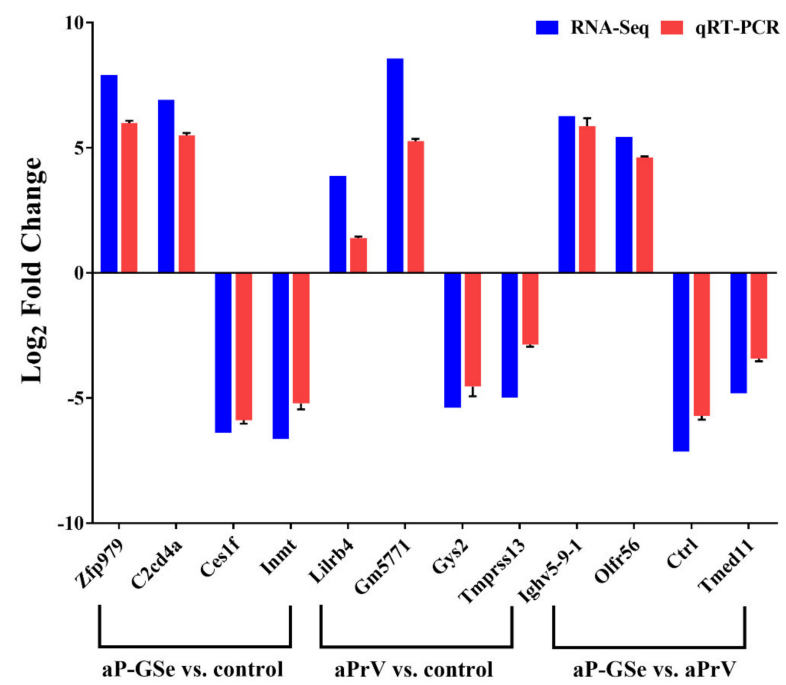

Figure 10. Validation of DEGs by RT-qPCR. Relative fold changes of DEGs from different comparations were normalized to the expression of GAPDH. Data are expressed as mean \pm SEM.

\section{Discussion}

Adjuvant effect of GSe was demonstrated on the immune response in neonatal mice. When GSe was co-administered with aPrV vaccine, specific gB antibody and cytokine (IL-2, IL-12, IFN- $\gamma$, IL-4, IL-6 and IL-10) responses were significantly increased in association with enhanced protection of vaccinated neonates against the lethal $\operatorname{PrV}$ challenge even though in the presence of MatAb. GSe-enhanced immune response depended on its use in the primary immunization. The mechanisms underlying may be due to more innate immune related pathways activated by GSe as analyzed by RNA-seq technology.

As the immune response of neonates and infants is poor to the infectious pathogens due to the immature immune system, MatAb acquired from the placenta and breast milk of mothers exerts an important role in protection of neonates from infection [24]. We observed that MatAb quickly declined when the neonates were nursed by mothers without immunization while MatAb sustained at a high level when the neonates were nursed by mothers immunized even though their biological mothers were not immunized (Figure 1). This result indicated that milk was the main resource for neonates to acquire MatAb. The similar results were observed by other studies. Yorty et al. reported that neonatal mice could attain herpes simplex virus specific maternal antibody from their mothers mainly by sucking breastmilk [25]. Yang et al. demonstrated that neonatal mice obtained rotavirus specific maternal antibody mainly from the milk of immunized mothers [18].

MatAb is important to protect animals from infection at early stage of life. However, MatAb declines soon in neonates after weaning, and eventually lose the protection. After reduction of MatAb and before elevation of vaccine induced antibody response, there is a window period when neonates easily attract diseases if exposed to infection $[3,4,26]$. We observed that all animals died after challenged with $\mathrm{fPrV}$ when neonatal mice were at 28 days old (Figure $2 \mathrm{c}$ ) and at 44 days old (Figure $4 \mathrm{c}$ ) with blocking rate of MatAb less than $30 \%$. Injection of aPrV vaccine induced gradually increased antibody response, survival animals increased after challenged with $\mathrm{fPrV}$ when neonatal mice were at day 49 (Figure 2c) and day 69 (Figure 4c) with blocking rate of antibody levels more than $30 \%$.

MatAb greatly inhibited production of antibody response induced by a vaccine. When neonates had low MatAb, aPrV-induced antibody response was already above the protective level on day 41 and 
then progressively increased (Figure $2 b$ ). However, aPrV-induced antibody response in neonates with high MatAb was around the protective level on day 41, and then progressively declined (Figure 4b). This difference may be due to neutralization of live viral vaccine by high level of MatAb. Crowe et al. found that viral replication of attenuated respiratory syncytial virus (RSV) vaccine was inhibited by the neutralizing effect of RSV specific MatAb in the lower respiratory tract of mice [27]. Siegrist et al. observed suppressed viral replication of live viral vaccines when MatAb was excessive, and resulted in inhibited B and T cell responses [28]. However, it is sometimes questioned to explain low immune response due to MatAb by inhibited replication of live vaccine virus because MatAb could also inhibit nonreplicating vaccine [29,30]. Johansson et al. found that suppressive effect of MatAb on rotavirus-like particle antigen was directly proportional to MatAb levels [31]. Even though the inhibitory effect of MatAb on vaccination is recognized [28,32], the exact mechanisms for MatAb to inhibit vaccination remain to be investigated. Kim et al.reported that the measles virus (MV) specific MatAb and live MV vaccine complex could cross-link the Fc $\gamma$-IIB receptor (Fc $\gamma$ RIIB) to BCR on the surface of B cells, resulting in inhibition of $B$ cell activation and specific antibody production in a cotton rat model [33]. Recently, Vono et al. demonstrated that MatAb could inhibit differentiation of germinal center (GC) B cells into plasma cells and memory B cells in a titer-dependent manner to interfere with vaccination in neonatal mice [34].

We previously demonstrated that GSe had adjuvant effect on aPrV vaccine [17]. Antibody response induced by aP-GSe was always higher than that induced by aPrV no matter that MatAb was low or high (Figures 2-4). Surviving animals were more in neonates immunized with aP-GSe than immunized with aPrV after challenged with fPrV (Figures 2c and 4c). Higher protection in aP-GSe group may be caused by higher gB antibody response [6,35], and activated NK cells and cytokine expression may also be possible contributors [36,37]. The window of susceptibility to PrV infection was shortened from 40 days to 36 days (Figure 2 b) or even closed (Figure $4 \mathrm{~b}$ ) when aP-GSe was used. These results indicated that susceptibility might be greatly decreased when GSe is co-administered with aPrV vaccine.

The maternal and fetal immune system is generally believed to skew toward Th2 immune responses in order to avoid spontaneous abortion [38]. In the present study, Th1 cytokines (IL-2, IL-12, IFN- $\gamma$ ) but not Th2 cytokines (IL-4, IL-6, IL-10) were significantly suppressed by MatAb when neonates were inoculated with aPrV vaccine alone (Figure 5). However, both Th1 and Th2 cytokines were significantly increased when $\mathrm{aPrV}$ vaccine was co-administered with GSe, especially the Th1 cytokines increased by larger margin. Adjuvant enhanced Th1 response has also been found in other studies. Millan et al. observed that hepatitis B surface antigen specific Th1 immune responses were stimulated when neonatal mice were injected with antigen formulated with adjuvant CpG [39]. Honda-Okubo et al. found that neonatal mice immunized with an inactivated influenza A/H1N1 vaccine together with adjuvant AdvaxTM significantly promoted IL-2 and IFN- $\gamma$ responses [40]. GSLS, the major constituent of GSe, has been found to promote Th1 cytokine production in mouse models [41-43]. Therefore, aP-GSe enhanced immune response found in this study could be related to increased cytokine production caused by GSLS, especially Th1 cytokine production.

Generally, the primary vaccination can affect the memory immune response. As a subtype of CD4 Th cells, $\mathrm{T}$ follicular helper (Tfh) cells play a critical role in GC formation and the generation of plasma cells and memory B cells [44-46]. Ciabattini et al. found that the improved humoral and cellular immune responses was dependent on the primary immunization after evaluation of the impact of primary and secondary immunization on the chimeric tuberculosis vaccine antigen $\mathrm{H} 56$ specific immune responses in mice [47]. Their previous study proved that the immune response could be elicited by a single immunization of the chimeric tuberculosis vaccine antigen $\mathrm{H} 56$ formulated with adjuvants, and adjuvant CAF01 and squalene-based oil-in-water emulsion could enhance Tfh and GC B cell immune responses [48]. Due to the inhibitory effect of MatAb, multiple vaccinations are usually needed in neonates to ensure a successful immunization. In this study, we observed that the antibody response was higher when the primary vaccine was aP-GSe and the antibody response was lower when $\mathrm{aPrV}$ was used in the primary vaccination irrespective of aP-GSe or aPrV used in the 
secondary immunization (Figure 6). Therefore, GSe might promote the development of Tfh and GC B cells, and generation of memory immune response. The results suggested that GSe could be included only in the primary immunization when it is used as an adjuvant to promote the immune response.

Different from the adults, the immune system of neonates is characterized by Th2 immune response bias, the low number of antigen-presenting cell (APC) and memory B cells, increased Treg cells, and reduced cytokine productions $[28,49,50]$. To investigate the underlying mechanisms of GSe as an adjuvant in neonates, splenocyte transcriptome was analyzed by RNA-seq technology. Data showed that the number of differentially expressed genes (DEGs) were significantly different among groups (Figure 7). The extremely high number of DEGs observed is likely due to cellular infiltration or a gross change in the composition of cell types that make up the spleen which, comprises T cells, B cells, monocytes, granulocytes, dendritic cells, natural killer cells, and macrophage, respectively (S1 and S2). Analysis of Gene ontology (GO) enrichment is a routine method to describe the gene function by identifying statistically enriched cellular components (CC), molecular functions (MF), and biological processes (BP) [21]. When compared to control, aP-GSe enriched more immune related GO terms than aPrV including "B cell activation", "regulation of B cell activation", "adaptive immune response", "positive regulation of leukocyte activation", "Lymphocyte mediated immunity" (Figure 8). Honda-Okubo et al. reported a novel adjuvant AdvaxTM could overcome the immature immunity of neonatal mice to enhance both humoral and cellular immune responses induced by A/H1N1. Moreover, it has been demonstrated that high protection provided by AdvaxTM-A/H1N1 was dependent on memory B cells [40]. Similarly, we also observed that high protection of neonates conferred by aP-GSe were associated with enhanced $\mathrm{gB}$ antibody responses. Hence, these data may indicate that aP-GSe could promote the development of $\mathrm{B}$ cells for neonates in presence of the MatAb.

Cellular immune responses are an important component of antiviral immunity. Herein, we observed that cytokine production related GO terms such as "cytokine receptor activity" as well as "positive regulation of cytokine secretion" were also enriched in aP-GSe vs. control group (Figure 8B). Some of previous animal studies reported the cellular immune responses after neonates or infants immunization in presence of MatAb were unaffected [51-54]. However, other studies showed the $\mathrm{Mat} \mathrm{Ab}$ inhibited or reduced cellular immune responses elicited by vaccines in neonates or infants $[55,56]$. The discrepancy may be attributed to different kinds of vaccines or antigens. In Figure 5, aP-GSe significantly enhanced Th1 type (IL-2, IL-12, and IFN- $\gamma$ ) and Th2 type (IL-4, IL-6, and IL-10) cytokine productions by splenocytes of neonates with MatAb. These results demonstrated that PrV specific $\mathrm{Mat} \mathrm{Ab}$ could inhibit the cellular immune responses of vaccinated neonates, which were similar to the previous study [56]. In addition, in comparison of aPrV, KEGG pathway "oxidative phosphorylation" was specially involved in aP-GSe (Figure 9C). Kolev et al. reported that oxidative phosphorylation played a critical role in $\mathrm{T}$ cell proliferation and activation [57]. Therefore, these observations indicated that GSe promoted Th1 type and Th2 type cytokine secretions even though in presence of MatAb may be attributed to the activation effect of GSe on T cells.

In association with aP-GSe promoted Th1 type and Th2 type cytokine productions, KEGG pathway analysis showed that "Th1 and Th2 cell differentiation" pathway was involved in aP-GSe vs. control (Figure 9B). BCG has been reported to elicit an effective neonatal Th1 immune responses via activating innate immunity [58-60], which suggested that suitable immune signals can help neonates trigger favorable immune responses. Due to defects in neonatal adaptive immune responses, activation of the neonatal innate immune responses exerts a vital role in the instruction of adaptive immunity including Th1 cytokine productions [61,62]. There are four major kinds of pattern recognition receptors expressed by APCs including toll-like receptors (TLRs), C-type lectin receptors (CLRs), Nod-like receptors (NLRs), and retinoic acid-inducible gene I (RIG-I)-like receptors (RLRs). These activated receptors could improve cytokine productions and activation of APCs to enhance the adaptive immune responses [63,64]. As a kind of APC, follicular dendritic cell (FDC) maturation is limited in neonatal mice $[65,66]$. However, FDC exerts an essential role in the interaction of antigen-specific $\mathrm{T}$ and $\mathrm{B}$ cells which is important for the induction of GC B and memory B cells [45]. Comparing KEGG results 
between aP-GSe vs. control and aPrV vs. control (Figure 9), more immune related pathways such as "NOD-like receptor signaling pathway", "Antigen processing and presentation", and "T cell receptor signaling pathway" were involved in aP-GSe vs. control. Particularly, we observed that KEGG pathway "antigen processing and presentation" was enriched in aP-GSe vs. aPrV. These data indicated that APCs could be activated by aP-GSe effectively. Vono et al. found that co-administered with influenza HA antigen and adjuvant CAF01 significantly enhanced GC B cell responses in neonatal mice, and which may result from the activation of CLRs [67]. Pind et al. demonstrated that adjuvants LT-K63, mmCT, MF59, and IC31 could improve the immune responses to a pneumococcal conjugate vaccine Pnc1-TT in neonatal mice via enhancing FDC maturation and GC B cell responses [68]. Therefore, aP-GSe-enhanced immune responses may result from the activation of the innate immunity of neonates.

\section{Conclusions}

In summary, neonatal mice acquired MatAb mainly from breastmilk. GSe had adjuvant effect on the immune response in neonatal mice. When GSe was co-administered with aPrV vaccine, specific gB antibody and cytokine (IL-2, IL-12, IFN- $\gamma$, IL-4, IL-6 and IL-10) responses were significantly increased in association with enhanced protection of vaccinated neonates against the lethal $\operatorname{PrV}$ challenge even though in the presence of MatAb. GSe-enhanced immune response depended on its use in the primary immunization. The mechanisms underlying may be due to more innate immune related pathways activated by GSe as analyzed by RNA-seq technology. These findings are valuable to use GSe as adjuvant to improve immunization using aPrV vaccine in piglets.

Supplementary Materials: The following are available online at http://www.mdpi.com/2076-393X/8/4/755/s1.

Author Contributions: S.H. and Y.W. (Yong Wang). designed the project and experiments. Y.W. (Yong Wang), L.Y., X.C. (Xuemei Cui), X.C. (Xiaoqing Chi), S.F., Z.L., M.L., Y.W. (Ye Wu), X.M. carried out most of the experiments. S.H., Y.W. (Yong Wang), L.Y., and W.X. wrote the manuscript, carried out statistical analysis and prepared figures. S.H. and Y.W. (Yong Wang) submitted this paper. All authors have read and agreed to the published version of the manuscript.

Funding: This study was supported by the National Natural Science Foundation of China (grant No. 31672598).

Acknowledgments: Special thanks are due to Yicheng Wang (Zhejiang Academy of Agricultural Sciences) for generously providing the field pseudorabies virus strain. The authors are also grateful to Lenan Zhuang, Xiaodan Ma, and Miss Sijia Fang for the help in taking care of mice during the COVID-19 outbreak.

Conflicts of Interest: The authors declare that the research was conducted in the absence of any commercial or financial relationships that could be construed as a potential conflict of interest.

\section{References}

1. Chase, C.C.L.; Hurley, D.J.; Reber, A.J. Neonatal immune development in the calf and its impact on vaccine response. Vet. Clin. N. Am. Food Anim. Pract. 2008, 24, 87-104. [CrossRef] [PubMed]

2. Gustafsson, E.; Blomqvist, G.; Bellman, A.; Holmdahl, R.; Mattsson, A.; Mattsson, R. Maternal antibodies protect immunoglobulin deficient neonatal mice from mouse hepatitis virus (MHV)-associated wasting syndrome. Am. J. Reprod. Immunol. 1996, 36, 33-39. [CrossRef] [PubMed]

3. Edwards, K.M. Maternal antibodies and infant immune responses to vaccines. Vaccine 2015, 33, 6469-6472. [CrossRef] [PubMed]

4. Hodgins, D.C.; Shewen, P.E. Vaccination of neonates: Problem and issues. Vaccine 2012, 30, 1541-1559. [CrossRef] [PubMed]

5. Garg, R.; Latimer, L.; Wang, Y.; Simko, E.; Gerdts, V.; Potter, A. Maternal immunization with respiratory syncytial virus fusion protein formulated with a novel combination adjuvant provides protection from RSV in newborn lambs. Vaccine 2016, 34, 261-269. [CrossRef] [PubMed]

6. Van Rooij, E.M.A.; Moonen-Leusen, H.W.; De Visser, Y.E.; Middel, W.G.J.; Boersma, W.J.A.; Bianchi, A.T.J. A DNA vaccine coding for $\mathrm{gB}$ and $\mathrm{gD}$ of pseudorabies virus (suid herpes type 1) primes the immune system in the presence of maternal immunity more efficiently than conventional vaccines. Vaccine 2006, 24, 1264-1273. [CrossRef] [PubMed] 
7. Sun, Y.; Luo, Y.; Wang, C.-H.; Yuan, J.; Li, N.; Song, K.; Qiu, H.J. Control of swine pseudorabies in China: Opportunities and limitations. Vet. Microbiol. 2016, 183, 119-124. [CrossRef] [PubMed]

8. Pomeranz, L.E.; Reynolds, A.E.; Hengartner, C.J. Molecular biololgy of pseudorabies virus: Impact on neurovirology and veterinary medicine. Microbiol. Mol. Biol. Rev. 2005, 69, 462-500. [CrossRef] [PubMed]

9. Yu, X.; Zhou, Z.; Hu, D.; Zhang, Q.; Han, T.; Li, X.; Gu, X.; Yuan, L.; Zhang, S.; Wang, B.; et al. Pathogenic pseudorabies virus, China, 2012. Emerg. Infect. Dis. 2014, 20, 102-104. [CrossRef]

10. Freuling, C.M.; Mueller, T.F.; Mettenleiter, T.C. Vaccines against pseudorabies virus (PrV). Vet. Microbiol. 2017, 206, 3-9. [CrossRef]

11. Brockmeier, S.L.; Lager, K.M.; Mengeling, W.L. Successful pseudorabies vaccination in maternally immune piglets using recombinant vaccinia virus vaccines. Res. Vet. Sci. 1997, 62, 281-285. [CrossRef]

12. Fischer, L.; Barzu, S.; Andreoni, C.; Buisson, N.; Brun, A.; Audonnet, J.C. DNA vaccination of neonate piglets in the face of maternal immunity induces humoral memory and protection against a virulent pseudorabies virus challenge. Vaccine 2003, 21, 1732-1741. [CrossRef]

13. Zou, M.; Yang, X.; Zheng, H.; Wang, H.; Li, L.; Sun, J.; Wang, F.; Wu, F.; Fan, G. Epidemiological survey of pseudorabies in some areas in China from 2012 to 2013. China Anim. Health Inspect. 2015, 32, 1-5.

14. Scheid, A.; Borriello, F.; Pietrasanta, C.; Christou, H.; Diray-Arce, J.; Pettengill, M.A.; Joshi, S.; Li, N.; Bergelson, I.; Kollmann, T.; et al. Adjuvant effect of bacille calmette-guerin on hepatitis B vaccine immunogenicity in the preterm and term newborn. Front. Immunol. 2018, 9, 29. [CrossRef]

15. Pomorska-Mol, M.; Markowska-Daniel, I. Interferon-gamma secretion and proliferative responses of peripheral blood mononuclear cells after vaccination of pigs against Aujeszky's disease in the presence of maternal immunity. FEMS Immunol. Med. Microbiol. 2010, 58, 405-411. [CrossRef]

16. Pomorska-Mol, M.; Markowska-Daniel, I.; Pejsak, Z. Evaluation of humoral and antigen-specific T-cell responses after vaccination of pigs against pseudorabies in the presence of maternal antibodies. Vet. Microbiol. 2010, 144, 450-454. [CrossRef]

17. Wang, Y.; Cui, X.; Yuan, L.; Maqbool, B.; Xu, W.; He, S.; Guan, R.; Hu, S. A solution with ginseng saponins and selenium as vaccine diluent to increase Th1/Th2 immune responses in mice. J. Immunol. Res. 2020, 2020. [CrossRef]

18. Yang, H.; Luo, G.; Zeng, Y.; Li, Y.; Yu, S.; Zhao, B.; Wang, Y.; Li, T.; Ge, S.; Xia, N. The distinct impact of maternal antibodies on the immunogenicity of live and recombinant rotavirus vaccines. Vaccine 2019, 37, 4061-4067. [CrossRef]

19. Cui, X.; Wang, Y.; Maqbool, B.; Yuan, L.; He, S.; Zhang, C.; Xu, W.; Hu, S. Early IgG response to foot and mouth disease vaccine formulated with a vegetable oil adjuvant. Vaccines 2019, 7, 143. [CrossRef]

20. Yuan, L.; Wang, Y.; Ma, X.; Cui, X.; Lu, M.; Guan, R.; Chi, X.; Xu, W.; Hu, S. Sunflower seed oil combined with ginseng stem-leaf saponins as an adjuvant to enhance the immune response elicited by Newcastle disease vaccine in chickens. Vaccine 2020, 38, 5343-5354. [CrossRef]

21. Xu, W.; Fang, S.; Wang, Y.; Zhang, T.; Hu, S. Molecular mechanisms associated with macrophage activation by Rhizoma Atractylodis Macrocephalae polysaccharides. Int. J. Biol. Macromol. 2020, 147, 616-628. [CrossRef] [PubMed]

22. Livak, K.J.; Schmittgen, T.D. Analysis of relative gene expression data using real-time quantitative PCR and the 2(-Delta Delta C(T)) Method. Methods 2001, 25, 402-408. [CrossRef] [PubMed]

23. Xu, W.; Fang, S.; Cui, X.; Guan, R.; Wang, Y.; Shi, F.; Hu, S. Signaling pathway underlying splenocytes activation by polysaccharides from Atractylodis macrocephalae Koidz. Mol. Immunol. 2019, 111, 19-26. [CrossRef] [PubMed]

24. Goldman, A.S. Evolution of the mammary gland defense system and the ontogeny of the immune system. J. Mammary Gland Biol. Neoplasia 2002, 7, 277-289. [CrossRef] [PubMed]

25. Yorty, J.L.; Schultz, S.A.; Bonneau, R.H. Postpartum maternal corticosterone decreases maternal and neonatal antibody levels and increases the susceptibility of newborn mice to herpes simplex virus-associated mortality. J. NeuroImmunol. 2004, 150, 48-58. [CrossRef]

26. Morein, B.; Abusugra, I.; Blomqvist, G. Immunity in neonates. Vet. Immunol. Immunopathol. 2002, 87, $207-213$. [CrossRef]

27. Crowe, J.E., Jr.; Firestone, C.Y.; Murphy, B.R. Passively acquired antibodies suppress humoral but not cell-mediated immunity in mice immunized with live attenuated respiratory syncytial virus vaccines. J. Immunol. 2001, 167, 3910-3918. [CrossRef] 
28. Siegrist, C.A. Mechanisms by which maternal antibodies influence infant vaccine responses: Review of hypotheses and definition of main determinants. Vaccine 2003, 21, 3406-3412. [CrossRef]

29. Bjorkholm, B.; Granstrom, M.; Taranger, J.; Wahl, M.; Hagberg, L. Influence of high titers of maternal antibody on the serologic response of infants to diphtheria vaccination at 3.; 5 and 12 months of age. Pediatr. Infect. Dis. J. 1995, 14, 846-850. [CrossRef]

30. Dagan, R.; Amir, J.; Mijalovsky, A.; Kalmanovitch, I.; Bar-Yochai, A.; Thoelen, S.; Safary, A.; Ashkenazi, S. Immunization against hepatitis $\mathrm{A}$ in the first year of life: Priming despite the presence of maternal antibody. Pediatr. Infect. Dis. J. 2000, 19, 1045-1052. [CrossRef]

31. Johansson, E.; Istrate, C.; Charpilienne, A.; Cohen, J.; Hinkula, J.; Poncet, D.; Svensson, L.; Johansen, K. Amount of maternal rotavirus-specific antibodies influence the outcome of rotavirus vaccination of newborn mice with virus-like particles. Vaccine 2008, 26, 778-785. [CrossRef] [PubMed]

32. Niewiesk, S. Maternal antibodies: Clinical significance, mechanism of interference with immune responses, and possible vaccination strategies. Front. Immunol. 2015, 5, 446. [CrossRef] [PubMed]

33. Kim, D.; Huey, D.; Oglesbee, M.; Niewiesk, S. Insights into the regulatory mechanism controlling the inhibition of vaccine-induced seroconversion by maternal antibodies. Blood 2011, 117, 6143-6151. [CrossRef] [PubMed]

34. Vono, M.; Eberhardt, C.S.; Auderset, F.; Mastelic-Gavillet, B.; Lemeille, S.; Christensen, D.; Andersen, P.; Lambert, P.-H.; Siegrist, C.-A. Maternal antibodies inhibit neonatal and infant responses to vaccination by shaping the early-life B cell repertoire within germinal centers. Cell Rep. 2019, 28, 1773-1784. [CrossRef] [PubMed]

35. Nakamura, T.; Ihara, T.; Nunoya, T.; Kuwahara, H.; Ishihama, A.; Ueda, S. Role of pseudorabies virus glycoprotein II in protection from lethal infection. Vet. Microbiol. 1993, 36, 83-90. [CrossRef]

36. Grabowska, A.K.; Lipinska, A.D.; Rohde, J.; Szewczyk, B.; Bienkowska-Szewczyk, K.; Rziha, H.-J. New baculovirus recombinants expressing pseudorabies virus (PRV) glycoproteins protect mice against lethal challenge infection. Vaccine 2009, 27, 3584-3591. [CrossRef]

37. Van Rooij, E.M.A.; De Bruin, M.G.M.; De Visser, Y.E.; Middel, W.G.J.; Boersma, W.J.A.; Bianchi, A.T.J. Vaccine-induced $\mathrm{T}$ cell-mediated immunity plays a critical role in early protection against pseudorabies virus (suid herpes virus type 1) infection in pigs. Vet. Immunol. Immunopathol. 2004, 99, 113-125. [CrossRef]

38. Levy, O. Innate immunity of the newborn: Basic mechanisms and clinical correlates. Nat. Rev. Immunol. 2007, 7, 379-390. [CrossRef]

39. Millan, C.L.B.; Weeratna, R.; Krieg, A.M.; Siegrist, C.A.; Davis, H.L. CpG DNA can induce strong Th1 humoral and cell-mediated immune responses against hepatitis B surface antigen in young mice. Proc. Natl. Acad. Sci. USA 1998, 95, 15553-15558. [CrossRef]

40. Honda-Okubo, Y.; Ong, C.H.; Petrovsky, N. Advax delta inulin adjuvant overcomes immune immaturity in neonatal mice thereby allowing single-dose influenza vaccine protection. Vaccine 2015, 33, 4892-4900. [CrossRef]

41. Song, X.; Bao, S.; Wu, L.; Hu, S. Ginseng stem-leaf saponins (GSLS) and mineral oil act synergistically to enhance the immune responses to vaccination against foot-and-mouth disease in mice. Vaccine 2009, 27, 51-55. [CrossRef] [PubMed]

42. Ni, J.; Bi, S.; Xu, W.; Zhang, C.; Lu, Y.; Zhai, L.; Hu, S. Improved immune response to an attenuated pseudorabies virus vaccine by ginseng stem-leaf saponins (GSLS) in combination with thimerosal. Antivir. Res. 2016, 132, 92-98. [CrossRef] [PubMed]

43. Li, R.; Ma, Y.; Zhai, L.; Lu, Y.; Chi, X.; Wu, J.; Hu, S. Enhanced immune response to foot-and-mouth disease vaccine by oral administration of ginseng stem-leaf saponins. Immunopharmacol. Immunotoxicol. 2016, 38, 257-263. [CrossRef] [PubMed]

44. Gavillet, B.M.; Eberhardt, C.S.; Auderset, F.; Castellino, F.; Seubert, A.; Tregoning, J.S.; Lambert, P.H.; De Gregorio, E.; Del Giudice, G.; Siegrist, C.A. MF59 mediates its b cell adjuvanticity by promoting T follicular helper cells and thus germinal center responses in adult and early life. J. Immunol. 2015, 194, 4836-4845. [CrossRef] [PubMed]

45. McHeyzer-Williams, M.; Okitsu, S.; Wang, N.; McHeyzer-Williams, L. Molecular programming of B cell memory. Nat. Rev. Immunol. 2012, 12, 24-34. [CrossRef] [PubMed]

46. Crotty, S. Follicular Helper CD4 T Cells (T-FH). Annu. Rev. Immunol. 2011, 29, 621-663. [CrossRef] [PubMed] 
47. Ciabattini, A.; Pettini, E.; Fiorino, F.; Lucchesi, S.; Pastore, G.; Brunetti, J.; Brunetti, J.; Santoro, F.; Andersen, P.; Bracci, L.; et al. Heterologous prime-boost combinations highlight the crucial role of adjuvant in priming the immune system. Front. Immunol. 2018, 9, 380. [CrossRef]

48. Ciabattini, A.; Pettini, E.; Fiorino, F.; Pastore, G.; Andersen, P.; Pozzi, G.; Medaglini, D. Modulation of primary immune response by different vaccine adjuvants. Front. Immunol. 2016, 7, 427. [CrossRef]

49. Siegrist, C.A. Neonatal and early life vaccinology. Vaccine 2001, 19, 3331-3346. [CrossRef]

50. Basha, S.; Surendran, N.; Pichichero, M. Immune responses in neonates. Expert Rev. Clin. Immunol. 2014, 10, 1171-1184. [CrossRef]

51. Siegrist, C.A.; Barrios, C.; Martinez, X.; Brandt, C.; Berney, M.; Cordova, M.; Kovarik, J.; Lambert, P.H. Influence of maternal antibodies on vaccine responses: Inhibition of antibody but not $\mathrm{T}$ cell responses allows successful early prime-boost strategies in mice. Eur. J. Immunol. 1998, 28, 4138-4148. [CrossRef]

52. Blomqvist, G.A.M.; Lovgren-Bengtsson, K.; Morein, B. Influence of maternal immunity on antibody and T-cell response in mice. Vaccine 2003, 21, 2022-2031. [CrossRef]

53. Crowe, J.E., Jr. Influence of maternal antibodies on neonatal immunization against respiratory viruses. Clin. Infect. Dis. 2001, 33, 1720-1727. [CrossRef] [PubMed]

54. Van Binnendijk, R.S.; Poelen, M.C.; Van Amerongen, G.; De Vries, P.; Osterhaus, A.D. Protective immunity in macaques vaccinated with live attenuated, recombinant, and subunit measles vaccines in the presence of passively acquired antibodies. J. Infect. Dis. 1997, 175, 524-532. [CrossRef]

55. Premenko-Lanier, M.; Hodge, G.; Rota, P.; Tamin, A.; Bellini, W.; McChesney, M. Maternal antibody inhibits both cellular and humoral immunity in response to measles vaccination at birth. Virology 2006, 350, 429-432. [CrossRef]

56. Bouma, A.; De Jong, M.D.; Kimman, T.G. The influence of maternal immunity on the development of the in vitro lymphocyte proliferation response against pseudorabies virus in pigs. Res. Vet. Sci. 1998, 64, 167-171. [CrossRef]

57. Kolev, M.; Dimeloe, S.; Le Friec, G.; Navarini, A.; Arbore, G.; Povoleri, G.A.; Povoleri, G.A.; Fischer, M.; Belle, R.; Loeliger, J.; et al. Complement regulates nutrient influx and metabolic reprogramming during Th1 cell responses. Immunity 2015, 42, 1033-1047. [CrossRef]

58. Marchant, A.; Goetghebuer, T.; Ota, M.O.; Wolfe, I.; Ceesay, S.J.; De Groote, D.; Corrah, T.; Bennett, S.; Wheeler, J.; Huygen, K.; et al. Newborns develop a Th1-type immune response to mycobacterium bovis bacillus calmette-guerin vaccination. J. Immunol. 1999, 163, 2249-2255.

59. Demirjian, A.; Levy, O. Safety and efficacy of neonatal vaccination. Eur. J. Immunol. 2009, 39, 36-46. [CrossRef]

60. Heldwein, K.A.; Liang, M.D.; Andresen, T.K.; Thomas, K.E.; Marty, A.M.; Cuesta, N.; Vogel, S.N.; Fenton, M. J. TLR2 and TLR4 serve distinct roles in the host immune response against Mycobacterium bovis BCG. J. Leukoc. Biol. 2003, 74, 277-286. [CrossRef]

61. Adkins, B.; Leclerc, C.; Marshall-Clarke, S. Neonatal adaptive immunity comes of age. Nat. Rev. Immunol. 2004, 4, 553-564. [CrossRef] [PubMed]

62. Firth, M.A.; Shewen, P.E.; Hodgins, D.C. Passive and active components of neonatal innate immune defenses. Anim. Health Res. Rev. 2005, 6, 143-158. [CrossRef] [PubMed]

63. Iwasaki, A.; Medzhitov, R. Control of adaptive immunity by the innate immune system. Nat. Immunol. 2015, 16, 343-353. [CrossRef] [PubMed]

64. Jain, A.; Pasare, C. Innate control of adaptive immunity: Beyond the three-signal paradigm. J. Immunol. 2017, 198, 3791-3800. [CrossRef]

65. Pihlgren, M.; Tougne, C.; Bozzotti, P.; Fulurija, A.; Duchosal, M.A.; Lambert, P.-H.; Siegrist, C.A. Unresponsiveness to lymphoid-mediated signals at the neonatal follicular dendritic cell precursor level contributes to delayed germinal center induction and limitations of neonatal antibody responses to T-dependent antigens. J. Immunol. 2003, 170, 2824-2832. [CrossRef]

66. Bjarnarson, S.P.; Adarna, B.C.; Benonisson, H.; Del Giudice, G.; Jonsdottir, I. The adjuvant LT-K63 can restore delayed maturation of follicular dendritic cells and poor persistence of both protein- and polysaccharide-specific antibody-secreting cells in neonatal mice. J. Immunol. 2012, 189, 1265-1273. [CrossRef] 
67. Vono, M.; Eberhardt, C.; Mohr, E.; Auderset, F.; Christensen, D.; Schmolke, M.; Coler, R.; Meinke, A.; Andersen, P.; Lambert, P.H.; et al. Overcoming the neonatal limitations of inducing germinal centers through liposome-based adjuvants including c-type lectin agonists trehalose dibehenate or curdlan. Front. Immunol. 2018, 9, 381. [CrossRef]

68. Pind, A.A.A.; Dubik, M.; Thorsdottir, S.; Meinke, A.; Harandi, A.M.; Holmgren, J.; Del Giudice, G.; Ingileif, J.; Stefania, P.B. Adjuvants enhance the induction of germinal center and antibody secreting cells in spleen and their persistence in bone marrow of neonatal mice. Front. Immunol. 2019, 10, 2214. [CrossRef]

Publisher's Note: MDPI stays neutral with regard to jurisdictional claims in published maps and institutional affiliations.

(C) 2020 by the authors. Licensee MDPI, Basel, Switzerland. This article is an open access article distributed under the terms and conditions of the Creative Commons Attribution (CC BY) license (http://creativecommons.org/licenses/by/4.0/). 